NBER WORKING PAPER SERIES

\title{
DOES COMPULSORY LICENSING DISCOURAGE INVENTION? EVIDENCE FROM GERMAN PATENTS AFTER WWI
}

\author{
Joerg Baten \\ Nicola Bianchi \\ Petra Moser \\ Working Paper 21442 \\ http://www.nber.org/papers/w21442 \\ NATIONAL BUREAU OF ECONOMIC RESEARCH \\ 1050 Massachusetts Avenue \\ Cambridge, MA 02138 \\ July 2015
}

\begin{abstract}
We wish to thank Tim Bresnahan, Dora Costa, Peter di Cola, Mark Duggan, Richard Epstein, Bob Hall, Walker Hanlon, Helen Kim, Wolfgang Keller, Steve Maurer, and seminar participants at the All-UC Group in Economic History, LSE, Northwestern Law, Queens, HBS, Hoover, Michigan, and UCLA for helpful comments and conversations. We are particularly grateful to Jochen Streb and Carsten Burhop for sharing copies of archival data, which allowed us to digitize the patent data. We also thank Petra Baten, Marianne Hock, Sarah Hueller, Katharina Koberski, Fred Panier, Minh Phan, Christopher Sung, and Mark Walsh for invaluable research assistance. Moser gratefully acknowledges financial support from the National Science Foundation through NSF Grant SES0921859, CAREER Grant 1151180, and CASBS. Bianchi thanks the Stanford Institute for Policy Research for financial support through the George P. Shultz Fellowship. The views expressed herein are those of the authors and do not necessarily reflect the views of the National Bureau of Economic Research.
\end{abstract}

NBER working papers are circulated for discussion and comment purposes. They have not been peerreviewed or been subject to the review by the NBER Board of Directors that accompanies official NBER publications.

(C) 2015 by Joerg Baten, Nicola Bianchi, and Petra Moser. All rights reserved. Short sections of text, not to exceed two paragraphs, may be quoted without explicit permission provided that full credit, including (C) notice, is given to the source. 
Does Compulsory Licensing Discourage Invention? Evidence From German Patents After WWI

Joerg Baten, Nicola Bianchi, and Petra Moser

NBER Working Paper No. 21442

July 2015

JEL No. N3,N32,N34,O3,O34,O38

\section{$\underline{\text { ABSTRACT }}$}

This paper investigates whether compulsory licensing - which allows governments to license patents without the consent of patent-owners - discourages invention. Our analysis exploits new historical data on German patents to examine the effects of compulsory licensing under the US Trading-with-the-Enemy Act on invention in Germany. We find that compulsory licensing was associated with a 28 percent increase in invention. Historical evidence indicates that, as a result of war-related demands, fields with licensing were negatively selected, so OLS estimates may underestimate the positive effects of compulsory licensing on future inventions.

Joerg Baten

Eberhard-Karls Universitaet

Tuebingen

Germany

joerg.baten@uni-tuebingen.de

Nicola Bianchi

Kellogg School of Management

Northwestern University

Leverone Hall, 6th Floor

2001 Sheridan Road

Evanston, IL 60208-2001

nicola.bianchi@kellogg.northwestern.edu
Petra Moser

Department of Economics

NYU Stern

44 West 4th Street

New York, NY 10012

and NBER

pmoser@stern.nyu.edu 
Whether policies that weaken intellectual property rights discourage invention is a subject of intense debate. Basic models indicate that weakening intellectual property rights discourages invention by reducing inventors' ability to recoup investments in R\&D (Scotchmer 2004, pp. 3536). But weaker intellectual property rights can also encourage cumulative (or follow-on) invention (Green and Scotchmer 1990, Scotchmer 1991, Murray et al. 2009) by enabling future inventors to build on patented ideas. ${ }^{1}$

A key mechanism to weaken intellectual property rights is compulsory licensing, which allows developing country governments to license foreign-owned patents to local firms without the consent of foreign patent owners. ${ }^{2}$ Article 31 of the Trade-Related Aspects of Intellectual Property Rights Agreement (TRIPS) allows compulsory licensing as a way to mitigate the potential welfare losses from TRIPS provisions that strengthen the patent rights of foreign firms (Bond and Saggi 2014). ${ }^{3}$ Countries, such as India, Thailand, and Brazil, have used it to provide affordable medicines for HIV and other life-threatening diseases.

Pharmaceutical firms, however, argue that compulsory licensing hurts consumers in the long run by discouraging invention due to "the risk of receiving only a drastically reduced royalty for the use of their intellectual property, imperiling in turn their ability to develop

\footnotetext{
${ }^{1}$ Historical analyses of innovations that were exhibited at world's fairs (as an alternative, nonpatent measure of innovation), indicate that most innovations were not patented (Moser 2012), and that countries without patent laws produced many important inventions (Moser 2013). Instead, the availability of patent protection appears to have influenced the direction of innovation (Moser 2005), and it may have encouraged the diffusion of ideas (Moser 2011). ${ }^{2}$ Compulsory licensing is also used as an instrument of antitrust policy (e.g., Chien 2003). In 2013, for example, the US Department of Justice and the US Patent and Trademark Office issued a joint statement to call for compulsory licenses on thousands of "standard-essential" patents (Policy Statement on Remedies for Standards-Essential Patents Subject to Voluntary F/RAND Commitments, January 8, 2013).

${ }^{3}$ In a stylized model of two agents (a developing country and a foreign patent-owner), in which the developing country is obligated to offer strong patents, the developing country's ability to issue a compulsory license makes both parties better off (Bond and Saggi 2014).
} 
profitably new treatments and molecules." ${ }^{\prime 4}$ In May 2015, for example, the pharmaceutical trade group Alafarbe warned that a compulsory license for Bristol Meyer's HIV drug Reyataz in Peru may cause "serious damage to the country and discourage investment.",

This paper exploits new individual-level data on German patents and a historical episode of compulsory licensing during World War I to examine the effects of compulsory licensing on inventors whose patents are licensed. As a source of quasi-experimental variation, it exploits the US decision in 1918 to make all enemy-owned US patents available for compulsory licensing. US authorities confiscated a total of 4,706 German-owned US patents under the TWEA; 1,246 of these patents were licensed to US firms. Licenses were non-exclusive and issued "upon equal terms and a royalty basis, to any bona fide American individual or corporation" (Haynes 1945, p. 260). Although the exact timing of licensing is unknown, most licenses were issued between 1919 and 1922 (Steen 2001). Moser and Voena (2012) have shown that compulsory licensing under the TWEA helped trigger an increase in US invention; in fields with licensing, US patents by domestic inventors increased by an additional 20 percent after 1918 . Previous work has, however, been unable to identify the effects on inventors whose patents are licensed, which is essential for understanding the welfare effects of this policy.

To perform this analysis, we have collected new historical data on all German patents for chemicals between 1900 and $1930 .{ }^{6}$ These data cover 79,591 patents issued by the German Patent Office (GPO) across 212 research fields of chemical inventions; 101 of these fields

\footnotetext{
${ }^{4}$ thepharmaletter, March 21, 2014.

${ }^{5}$ Ed Silvermann, Wall Street Journal "Bristol-Myers Faces a Compulsory License for an AIDS Drug in Peru" May 2015.

${ }^{6}$ We focus on chemicals and pharmaceuticals because these industries are important targets for compulsory licensing, and patents are exceptionally effective as a mechanism to protect chemicals and pharmaceuticals (Levin et al. 1987, Harhoff et al. 1999, Cohen, Nelson, and Walsh 2000), so that patent data are a useful proxy for invention.
} 
include at least one licensed patent. To investigate firm-level changes in patenting, we match GPO patents with information on German firms. 30,499 patents were assigned to 4,814 firms; 50 of them saw at least one of their patents licensed under the US TWEA.

Baseline specifications compare changes in German patents after 1918 across research fields that were differentially affected by compulsory licensing in the United States. This difference-in-differences approach allows us to examine the effects of compulsory licensing controlling for unobservable factors, such as reparations and punitive tariffs, which also may have influenced German invention. We also control for patents by foreign inventors as a proxy for changes in demand, scientific breakthroughs, or other factors that may have encouraged patenting in Germany, irrespective of compulsory licensing. This analysis indicates that German inventors began to patent more after 1918 in research fields in which their patents had been licensed. German inventors applied for 2.97 additional patents per year after 1918 in fields with licensing compared with other fields of chemical invention. Relative to a pre-1918 average of 10.77 this implies a 28 percent increase.

A concern with the baseline OLS regressions is that US firms may have been more likely to license German-owned US patents in fields in which US demand for invention was high, and German demand for invention may have increased in the same fields. Then, OLS estimates overstate the increase in invention that is due to licensing. Historical evidence, however, indicates that US firms were most likely to license German-owned patents in war-related research fields, such as dyestuffs and explosives, which faced severe problems of excess capacity after the war (Haber 1971, p. 251). Then, OLS under- rather than overestimates the increase in patenting that is due to licensing. To address this issue, we exploit the fact that the US Alien Property Custodian confiscated all German-owned patents - irrespective of variation in demand - 
and that only confiscated patents were available for licensing. Instrumental variable regressions with confiscated patents indicate that OLS estimates are downward biased.

As an additional test, we use inventors' decisions to pay renewal fees to capture variation in the valuation of patents (following Schankerman and Pakes 1986). This analysis suggests that some of the observed increase in patenting may have been due to an increase in lower-quality, strategic patents. Even for high-quality patents, however, our estimates indicate an additional 17 percent increase in invention in fields with licensing after 1918.

Finally, inventor-level analyses of patenting suggest that firms whose patents had been licensed applied for an additional 0.42 patents per year after 1918 in fields with licensing compared with other German firms. Relative to an average of 0.46 patents per firm, field, and year until 1918, this implies a 91-percent increase. Inventor-level analyses also reveal a substantial differential increase in the number of active patentees in fields with licensing, which indicates an increase in entry. Consistent with theoretical predictions about the link between competition and innovation (Arrow 1962, Aghion et al. 2005) we find that the observed increase in patenting was strongest for fields in which pre-existing levels of competition were low. Taken together, these results suggest that compulsory licensing may be particularly effective in promoting invention by increasing the threat of competition in fields with low pre-existing levels of competition.

\section{DATA}

This paper examines a new historical data set of 79,591 patents for chemicals in Germany between 1900 and 1930. Our data expand on existing aggregate-level data on German patents (for example, Richter and Streb 2011) by including data on inventors' countries of residence, 
renewal decisions, and firm-level identifiers. This section presents a brief overview of the data; a data appendix provides more detail.

\section{A. Patents across Research Fields, 1900-1930}

Our data start with patent applications in 1900, the first year in which the GPO systematically assigned all patents to fine-grained subclasses, which allow us to define research fields. ${ }^{7}$ Data include patent applications until 1930, the last cohort of patent applications that were issued before 1933, when the Nazi government dismissed Jewish scientists from universities and other types of public sector jobs. ${ }^{8}$

Among 212 subclasses of chemical invention, 167 include at least one confiscated patents, and 101 include at least one licensed patent. ${ }^{9}$ The average subclass with at least one licensed patent includes 18 licensed and 5 confiscated patents (with a standard deviation of 53.65 and 64.33, respectively, Appendix Table A2). Five subclasses include more than 100 licensed patents: 22a azo dyes (436 licensed patents), 12o hydrocarbons (242), 12i metalloids (146), 12q aminophenol (110), and 12k ammonia (108).

To assign inventor nationalities to all German patents, we extract text strings with the inventor's city of origin from each patent. 58,691 of 79,591 German patents are by German inventors. The other 20,900 German patents are by foreign inventors, including 4,133 by

\footnotetext{
${ }^{7}$ An 1891 reform introduced product patents for chemicals; until 1891 Germany only granted process patents for chemicals (Haber 1971, p. 218). Until 1900, patents were assigned to 89 numerical classes; in 1900 the German Patent Office reformed this classification to create 513 alphanumeric subclasses.

${ }^{8}$ The April 7, 1933 Law for the Restoration of Public Service dismissed all professors with a Jewish grandparent. Analyses of US patents indicate that dismissed German-Jewish scientists who moved to the United States created substantial benefits for US invention (Moser, Voena, and Waldinger 2014).

${ }^{9}$ Based on the classification of patents in the Systematische Übersicht der vom 1. Januar bis 31. Dezember 1912 in die Patentrolle eingetragenen Patente (1912).
} 
inventors from the United States, 3,162 from Great Britain, 3,041 from France, 2,984 from

Switzerland, and 1,458 from Austria. ${ }^{10}$

Data on German patents by US inventors allow us to check whether compulsory licensing led to an increase in US invention (Moser and Voena 2012, pp. 404-5). These data confirm that US invention increased significantly more in fields with licensing (Figure 1). Between 1900 and 1918, US firms applied for 0.67 patents per year in fields with licensing, compared with 0.56 in other fields. After 1918, US firms applied for 0.91 additional patents per year in fields with licensing compared with 0.37 in other fields.

\section{B. Renewal Decisions to Proxy Patent Value}

Griliches (1990, p. 1669) observes that patents “differ greatly in 'quality,' in the magnitude of inventive output associated with them." To measure such variation, Schankerman and Pakes (1986) propose to use inventors' decisions to pay renewal fees to capture variation in the private value of patents. Harhoff et al. (1999) document a positive correlation between inventors' reported valuation of patents and the number of years for which inventors renewed their patents. Lanjouw et al. (1998), however, caution that researchers cannot observe the true valuation of patents that are renewed for the full term, if renewal fees are low. ${ }^{11}$

\footnotetext{
${ }^{10}$ A small number of Austrian-owned US patents, 32 patents, were subject to compulsory licensing under the TWEA. To be conservative, we exclude these patents from the treatment variable, and assign German patents by Austrian inventors to the control variable patents by other foreign inventors.

${ }^{11}$ Patent citations, as an alternative measure of patent quality, are not available for German patents because references to prior art were not recorded. Trajtenberg (1990) shows that counts of citation are correlated with the estimated social surplus of 456 patented improvements in CT scanners. Moser, Ohmstedt, and Rhode (2014) link patents with field trial data for hybrid corn, and show that citations are correlated with improvements in yields, as an objective measure for the size of patented inventions. They do, however, also find that citation counts for early patents may overstate their value because these patents are cited to establish patentability.
} 
In Germany, renewal fees were high, so that renewal decisions were economically meaningful. In the first two years, renewal fees were $50 \mathcal{M}$ per year (Appendix Figure A2); this is equivalent to $\$ 243$ in 2012 using purchasing power (the most conservative conversion) and $\$ 1,340$ using income value (the largest estimate, Williamson 2014). ${ }^{12}$ After the second year, renewal fees increased by $50 \mathcal{M}$ each year, reaching $700 \mathcal{M}$ in the 15 th year, which was the end of the statutory term. To renew a patent for 5 years inventors had to pay $550 \mathcal{M}$, between $\$ 2,670$ and $\$ 14,700$ in $2012 .^{13}$

To construct renewal data, we followed all 79,591 GPO patents for chemicals through renewal records in the Annual Reports of the German Patent Office, 1901-1942. Half of all patents - 39,682 (49.86 percent) - were renewed for 5 years or more; we use these patents as a proxy for high-value patents. ${ }^{14} 14,605$ patents were not renewed in the first year (18.35 percent), 18,319 (23.02 percent) were renewed for 10 years or more, and 6,089 (7.65 percent) were renewed for the full 15-year term (Appendix Figure A3).

\section{Inventor-level Changes in Patenting}

To investigate inventor-level changes in patenting, we match patents with German firms; this process matches 30,499 GPO patents with application years between 1900 and 1930 to 4,814 unique German firms. The remaining 49,092 German-owned patents were issued to individual

\footnotetext{
${ }^{12}$ In $1915,50 \mathcal{M}$ were equal to $\$ 10.31$ (Bidwell, 1970).

${ }^{13}$ By comparison, US renewal fees were only $\$ 1,600$ in 2012 and 2014, due 3.5 years after the issue date. http://www.uspto.gov/web/offices/ac/qs/ope/fee010114.htm; accessed March 2, 2014.

${ }^{14}$ Another benefit of using five years as a cut-off is that our quality measure is unlikely to be affected by a September 19, 1914 decision of Germany's Federal Council (Bundesrat) to suspend renewal fees; this suspension lasted nine months. In 1918, the German Patent Office announced that patentees had to pay fees for the last four years to keep their patents active (Blatt 1918, p. 98). As a result, any patent that was renewed for five years or more has been subject to the full fees. In the main analysis we address the issue of this suspension and other war-related disruptions through robustness checks that exclude the war years (1914-1919) from the sample.
} 
inventors; in firm-level regressions, we use these patents as a control for scientific

breakthroughs, changes in demand, or other unobservable factors that may influence changes in patenting across fields.

Firm-level patent data allow us to investigate changes in patenting for firms that were differentially affected by compulsory licensing. 1,017 of 1,246 licensed patents were owned by a total of 50 German firms (using records from Haynes 1945 and the Alien Property Custodian 1919, see Data Appendix). Another 229 licensed patents list the US Chemical Foundation as an assignee owner. The remaining 208 patents are owned by individuals, including 53 patents by co-inventors of a German firm. For example, Dr. Richard Herz from Frankfurt is listed as an inventor for US patents 956348, 960919, and 966092 of the German firm Cassella, and we assign one remaining US patent by Dr. Herz (US patent 1243171) to the same firm.

The firms that were most affected by licensing were the German Bayer AG (551 licensed patents), the Badische Anilin und Soda Fabrik (BASF, 308 licensed patents), Meister Lucius (104 licensed patents), Griesheim-Elektron (57), AGFA (38), Cassella (22), and the BerlinAnhaltische Maschinenbau AG (BAMAG, 17). Another 43 firms saw between 1 and 12 of their US patents licensed under the TWEA. 12,531 patents by these 50 German firms cover 123 subclasses in the German patent system, and 17,968 patents by 4,764 firms without licensed patents cover 202 subclasses. ${ }^{15}$

Data on firm size, which we draw from a registry of publicly traded joint stock companies (Handbuch der Deutschen Aktiengesellschaften 1911 and 1912) indicate that firms with licensed patents were large compared with other German firms. A total of 4,814 firms

${ }^{15}$ Another 28,192 patents by individual inventors cover 208 research fields. Although individual inventors were less likely to patent in the United States than German firms, some individual inventors may have been affected by compulsory licensing. Analyses at the firm level exclude these data. 
applied for at least one chemical patent in Germany between 1900 and 1930; 175 of them (3.6 percent) are listed in the registries of Aktiengesellschaften (AGs). Thirty of 50 firms with licensed patents were AGs, compared with 145 of 4,764 other firms (Appendix Table A3). On average, 30 AGs with licensed patents had a nominal capital stock of \$108,343, compared with \$40,755 for 145 other AGs in our sample (from Handbuch 1911 and 1912, in year 2012 dollars). ${ }^{16}$ Data on employees are available for 13 AGs with licensed patents and 50 other AGs. On average, AGs with licensed patents had 6,197 employees in 1911 and 1912 (with a median of 1,060, and a standard error of 4,867), compared with 2,466 employees for other 50 German AGs (with a median of 881, and a standard error of 963).

In terms of firm age, firms with and without licensed patents are roughly comparable:

The average AG with licensed patents had been incorporated as a joint-stock company in 1893 (with a standard error of 2.6 years). By comparison, the average AG without licensed patents had been incorporated as a joint-stock company in 1892 (with a standard error of 1.3 years).

\section{RESULTS}

Comparisons of means indicate that German inventors began to patent more in research fields with licensing after 1918. In 101 fields with licensing, patent applications by German inventors increased by 53 percent from 10.77 per year until 1918 to 16.49 afterwards (Table 1,

\footnotetext{
${ }^{16}$ Firms with and without licensed US patents report comparable valuations of patents on their balance sheets. Haber (1971, p. 254), however, warns, “... when we look at the finance of chemical companies just before and just after the war, we have a woefully small sample, the information is inadequate and the conclusions must necessarily be tentative." Fourteen of 30 firms with licensed patents reported patents among the assets on their balance sheets; four (13.3 percent) of them listed a positive value; eight (26.7 percent) reported a symbolic 1 Mark for devalued patented assets. By comparison, 63 of 145 firms without licensed patents reported patents among their assets; 19 (13.1 percent) of them listed a positive value, 43 (29.7 percent) listed a symbolic value of 1 Mark.
} 
Panel A). By comparison, in 111 fields without licensing, patenting increased by less than 10 percent from 5.05 until 1918 to 5.54 afterwards.

Annual patent data show fields with licensing produced more patents per year in the prewar period (until 1918, Appendix Figure A4, Panel A). These data also suggest that patenting may have begun to increase at a slightly higher rate for fields with licensing before 1918. In the regressions, we will address this issue through alternative controls for pre-trends; results are robust to controlling for these trends.

Most notably, German inventors began to patent significantly more in fields with licensing after 1919, while patenting stayed flat in other fields. To investigate these changes systematically with controls, we estimate:

$$
\begin{aligned}
\text { (1) } \text { patent }_{c t}= & \beta_{0}+\beta_{1} \bullet \text { field with licensed patent } s_{c} \bullet \text { post }_{t} \\
& +\beta_{2} \bullet \text { patents by US inventors } s_{c t}+\beta_{3} \bullet \text { patents by other foreign inventors } s_{c t} \\
& +\delta_{t}+\theta_{c}+\varepsilon_{c t}
\end{aligned}
$$

where the dependent variable patents ${ }_{c t}$ measures the number of successful applications for German patents by German inventors in field $c$ and year $t$ between 1900 and 1930. The variable field with licensed patents ${ }_{c}$ equals 1 for research fields in which at least one German-owned patent was licensed under the US TWEA. The variable post $_{t}$ indicates years after 1918. Under the assumption that - in the absence of compulsory licensing - changes in patenting would have been comparable in fields with and without licensing, the coefficient $\beta_{l}$ measures the effect of compulsory licensing on German invention.

Three variables control for idiosyncratic variation in patenting across research fields and over time. The variables patents by US inventors $s_{c t}$ and patents by other foreign inventors ${ }_{c t}$ control for variation in German patents by US and other foreign inventors across fields and over time. Field fixed effects $\theta_{c}$ control for variation across fields that is constant over time. Year 
fixed effects $\delta_{t}$ control for variation in patenting over time that affects all fields. Standard errors are clustered at the level of research fields.

OLS estimates indicate that German inventors applied for 2.97 additional patents per year after 1918 in research fields with licensing (Table 2, column 1, p-value 0.001). Compared with an average of 10.77 patents per year until 1918 for these fields, this implies a 28 percent increase. Excluding controls for GPO patents by foreign inventors increases the coefficient to 5.22 (Table 2, column 2, p-value 0.001).

Comparisons across fields indicate that research fields with 10 or more licensed patents experienced the largest increase in invention (Appendix Figure A4, Panel B). Until 1918, changes in patenting were similar in fields with small and large numbers of licensed patents. After 1918, patenting accelerated disproportionately in research fields with 10 or more licensed patents. In 1928, inventors applied for an average of 38.4 patents per year in fields with 10 or more licenses, compared with 17.41 in fields with 3 to 10 licenses, 11.92 in fields with 2 licenses and 6.17 patents in fields with fewer than 2 licenses.

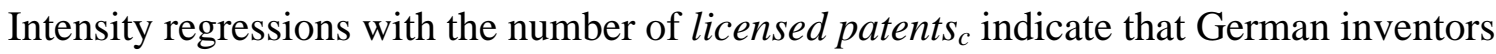
applied for 0.20 additional patents per year after 1918 for each additional patent that was licensed in field $c$ (Table 2, column 5, p-value 0.005). For the average field with at least one licensed patent, which includes 18.04 licensed patents, this implies a 33.5 percent increase.

\section{A. Controlling for Differential Pre-Trends}

As a robustness check, we re-estimate the baseline specification allowing for separate linear pre-trends in patenting for each research field:

(2) patents $_{c t}=\beta_{0}+\beta_{1} \bullet$ field with licensed patents ${ }_{c} \bullet$ post $_{t}$ $+\beta_{2} \bullet$ patents by US inventors $s_{c t}+\beta_{3} \bullet$ patents by other foreign inventors $s_{c t}$ 


$$
+\Sigma_{\mathrm{c}} \phi_{c} \cdot \text { field }_{c} \bullet \operatorname{preTWEA}_{t} \cdot t+\delta_{t}+\theta_{c}+\varepsilon_{c t}
$$

where field $d_{c}$ is a vector that distinguishes 212 research fields within chemicals, the indicator variable preTWEAt equals 1 for years before 1919, and the variable $t$ denotes a linear time trend. Estimates with these field-specific pre-trends indicate that German inventors applied for 5.32 additional patents per year after 1918 in fields with licensing (Table 2, column 3, p-value $<0.001$ ), which implies a 49 percent increase.

We also estimate $\beta_{1}$ separately for each year with 1918 to 1921 as the omitted category (Appendix Figure A5). Until 1917, effects are negative and statistically significant only for 4 of 18 years. After 1918 effects are positive and statistically significant for 5 of 12 years. Estimates increase after 1923, with 3.58 additional patents in 1924 and 3.68 in 1925, implying a 33 and 34 percent increase, respectively (with p-values of 0.006 and 0.013 ).

An alternative test allows for a separate linear pre-trend for fields with licensing: (3) patents $_{c t}=\beta_{0}+\beta_{1} \bullet$ field with licensed patents $\boldsymbol{s}_{c} \cdot$ post $_{t}$ $+\beta_{2} \cdot$ patents by US inventors $s_{c t}+\beta_{3} \bullet$ patents by other foreign inventors $s_{c t}$ $+\beta_{4} \bullet$ field with licensed patents ${ }_{c} \bullet \operatorname{preTWEA}_{t} \bullet t+\delta_{t}+\theta_{c}+\varepsilon_{f c t}$

These regressions indicate an increase by 5.02 additional patents per year after 1918 (Table 2, column 4 , p-value $<0.001$ ), which is larger than the baseline estimate of $2.97 .{ }^{17}$

\section{B. Excluding the War Years}

An additional robustness check excludes the war years (1915-1918). For example, patenting during these years may have been influenced by changes in the demand for war-related chemicals, such as explosives and dyes. These estimates are slightly larger than the baseline estimate of 2.97 additional patents (Table 2, column 1). OLS estimates indicate that German

${ }^{17}$ The coefficient of the linear trend for fields with licensing is small $(0.204$, p-value 0.007$)$. 
inventors applied for 3.22 additional patents in fields with licensing per year after 1918 (Appendix Table A4, column 1, p-value 0.001). Excluding controls for patents by foreign inventors increases the size of this estimate to 5.36 (Appendix Table A4, column 2, p-value 0.001). Intensity specifications indicate that German inventors applied for 0.19 additional patents per year after 1918 for each additional licensed patent ${ }_{c}$ (Appendix Table A4, column 5, p-value 0.007), which implies a 32 percent increase for the average field with at least 1 licensed patent.

\section{Instrumental Variable Regressions}

We also examine the potential influence of selection into compulsory licensing. As a response to Germany's military aggression, the confiscation of German-owned property and the timing of the TWEA were exogenous to changes in patenting after 1918. The fields in which US firms chose to license confiscated US patents by German inventors may, however, not have been exogenous. Most importantly, US firms may have been more likely to license German-owned US patents in fields in which US demand for invention was high, and German demand may have increased in the same fields after 1918, resulting in an increase in invention. Then, OLS estimates overstate the increase in invention that is due to licensing.

Historical accounts, however, indicate that US firms were more likely to license Germanowned patents for war-related chemicals, such as dyes or explosives. In these fields, German firms were affected by a dramatic decline in demand after 1919. Haber (1971, p. 251), for example, explains that: "Without demand for war-related chemicals, the worst problem that German dye producers...faced turned out to be excess capacity.” Thus, the historical records suggest that selection into licensing may have been negative in the case of German patents. Consistent with negative selection as a result of war-related research demands, the field with the 
largest number of licensed patents was subclass 22a for azo dyes, with 436 licensed patents (Appendix Table A5). In this field, patents by German inventors declined from 28.79 per year until 1918 to 24.17 afterwards.

To investigate these issues, we estimate intent-to-treat (ITT) and instrumental variable (IV) regressions with fields with confiscated patents as an instrument for fields with licensed patents. These regressions exploit the fact that only confiscated patents were available for licensing (so that fields with confiscated patents were more likely to become fields with licensing), and that changes in patenting after 1918 did not influence the choice of confiscated fields (because all German-owned US patents were confiscated in 1918.) ITT (or reduced form) regressions estimate

(4) patents $_{c t}=\beta_{0}+\beta_{1} \bullet$ field with confiscated patents ${ }_{c} \bullet$ post $_{t}$ $+\beta_{2} \cdot$ patents by US inventors $s_{c t}+\beta_{3} \bullet$ patents by other foreign inventors $s_{c t}$ $+\delta_{t}+\theta_{c}+\varepsilon_{c t}$

where field with confiscated patents $s_{c}$ equals 1 if field $c$ includes at least 1 confiscated Germanowned US patent. Among 212 research fields of chemical inventions, 167 fields include at least 1 confiscated patent; 101 of these 167 fields with confiscated patents include at least 1 licensed patent (60 percent). ITT estimates imply that German inventors applied for 2.36 additional patents per year after 1918 in fields with confiscated patents (Table 3, column 1, p-value 0.004). Compared with an average of 10.77 patents per field and year until 1918, this implies a 22 percent increase.

Consistent with historical evidence of negative selection (e.g., Haber 1971, p. 251), ITT estimates suggest that OLS may underestimate the effects of compulsory licensing. At 2.36 (Table 3, column 1), ITT estimates are 33 percent larger than 1.78, the product of the OLS 
estimate of 2.97 (Table 2, column 1) and 0.60, the probability that at least one patent in a field with confiscated patents was licensed. ${ }^{18}$

IV regressions that use fields with confiscated patents s $_{c}$ as an instrument for fields with licensed patents $s_{c}$ confirm that OLS is downward biased. First stage regressions indicate that a field with confiscated patents is 58 percent more likely to be a field with licensed patents (Table 3, column 4, p-value $<0.001)$. IV estimates indicate that German inventors applied for 4.05 additional patents per year after 1918 in fields with licensing (Table 3, column 6, p-value < 0.001), compared with 2.97 for OLS (Table 2, column 1).

The local average treatment effect (LATE) of 4.05 measures the effect of making German-owned US patents available for compulsory licensing by US firms in fields in which German inventors applied for US patents between 1900 and 1918. Inventions in these fields are geared towards the US market, and (due to the costs of patenting abroad) they are more likely to be owned by larger German firms. ${ }^{19}$

\section{Renewals as a Control for Patent Value}

We also examine whether the observed increase in patenting may be due to lower quality, strategic patents. Following Schankerman and Pakes (1986), we use information that we collect on inventors' decisions to pay renewal fees as a measure of variation in inventors' valuation of patents. Patents that inventors renewed for at least 5 years (the median renewal year) serve as a proxy for high-value patents. Estimates with renewed patents imply a large and statistically

\footnotetext{
${ }^{18}$ ITT estimates with patents that were renewed for at least 5 years imply a 19 percent increase in patenting in GPO research fields with confiscated patents (Appendix Table A6, column 1).

${ }^{19}$ See the description of the firm characteristics in the data section and Appendix Table A.3.
} 
significant increase in high-value patents. ${ }^{20}$ Renewed patents follow a similar trend for fields with and without licensing until 1918 (Appendix Figure A6, Panel A). After 1918, renewed patents increased in fields with licensing but not in other fields. In 1927, German inventors applied for 9.63 renewed patents in fields with licensing, more than three times compared with 2.29 in other fields. In fields with licensing, counts of renewed patents increased by 28 percent from 6.28 per year until 1918 to 8.05 after 1918 (Table 1, Panel A). In fields without licensing, renewed patents declined by 12 percent from 2.56 per year until 1918 to 2.28 afterwards.

Estimating the baseline specification (equation 1) with renewed patents as an outcome variable indicates that German inventors applied for 1.09 additional renewed patents per year after 1918 in fields with licensing (Table 2, column 7, p-value 0.02). Compared with an average of 6.28 renewed patents per field and year until 1918, this implies a 17 percent increase. Estimates with field-specific pre-trends indicate that German inventors applied for 2.35 additional renewed patents (Table 2, column 8, p-value 0.001 ), implying a 37 percent increase. Regressions with a separate trend in patenting for fields with licensing indicate that German inventors applied for 2.26 additional renewed patents per field and year, implying a 36 percent increase (not reported). Intensity regressions indicate that German inventors applied for 0.08 additional renewed patents per year after 1918 for each additional licensed patent ${ }_{c}$; this implies a 23 percent increase for the average field with at least one licensed patent.

\footnotetext{
${ }^{20}$ For example, inventors may have responded to the loss of their US patents by building a "patent thicket," which Shapiro (2001, p. 120) defines as a "dense web of overlapping intellectual property rights that a company must hack its way through in order to actually commercialize a new technology." For a sample of 95 semiconductor firms between 1979 and 1995, Hall and Ziedonis (2001) show that firms build portfolios of strategic patents to use against each other in case of litigation.
} 


\section{INVENTOR-LEVEL CHANGES IN PATENTING}

In this section we investigate the claim that firms will reduce their spending on $R \& D$ in research fields with compulsory licensing. Specifically, we estimate triple difference regressions of the form:

$$
\begin{aligned}
& \text { (5) patents } f_{f t}=\gamma_{0}+\gamma_{1} \bullet \text { field } w \text { licensed patents } s_{c} \bullet \text { firm } w \text { licensed patent } \text { li }_{f} \cdot \text { post }_{t}
\end{aligned}
$$

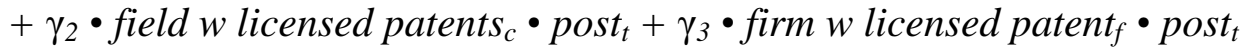

$$
\begin{aligned}
& +\gamma_{4} \bullet \text { field } w \text { licensed patents }_{c} \bullet \text { firm } w \text { licensed patent }_{f} \\
& +\gamma_{5} \bullet \text { patents by US inventors } \text { it }+\gamma_{6} \bullet \text { patents by other foreign inventors } s_{c t} \\
& +\gamma_{7} \bullet \text { patents by individuals } s_{c t}+\delta_{t}+\theta_{c}+\lambda_{f}+\varepsilon_{f c t}
\end{aligned}
$$

where the outcome variable patent $s_{f c t}$ counts patents by firm $f$ in field $c$ and application year $t$. The variable firm $w$ licensed patent $f$ equals 1 if at least one of firm $f$ 's patents was licensed. The variable patents by individuals $s_{c t}$ counts patents in field $c$ and year $t$ by individual German inventors; all other control variables are as defined above. The triple difference coefficient $\gamma_{1}$ measures the effect of compulsory licensing on firms whose patents were licensed, compared with other German firms. It is an unbiased estimate of the effect of compulsory licensing on firms whose patents were licensed if changes in patenting in field $c$ after 1918 would have been comparable for firms with and without licensed patents in the absence of compulsory licensing.

OLS estimates indicate that firms whose patents had been licensed began to patent more in fields with licensing after 1918. German firms with licensed patents applied for 0.42 additional patents per year after 1918 in fields with licensing (Table 4, column 1, p-value 0.002). Compared with a mean of 0.46 patents per field and year until 1918 for firms with licensed patents, this implies a 91 percent increase. These results are robust to the inclusion of fieldspecific pre-trends (Table 4, column 2). 


\section{A. Excluding Years after the Creation of IG Farben}

An additional robustness check excludes application years after 1924, the last year before the creation of the IG Farben. The cartel-like "community of interest" (in German Interessengemeinschaft, or IG) formed on December 25, 1924. It included the largest firms in the German chemical industry: AGFA, Bayer, BASF, Hoechst, Griesheim-Elektron, and Chemische Fabrik (vorm. Weiler Ter Meer). Haber (1971, pp. 290-91) explains: "In the latter half of the 1920s, the German chemical industry employed nearly 0.3 million people, and on this reckoning IG Farben accounted for over a third." 21 To mitigate competition, members of the IG Farben specialized in specific chemicals. After the creation of IG Farben,

"the Leverkusen works of Bayer increased their make of dyes by over a quarter, ...Hoechst was assigned responsibility for all chemicals from acetylene, and in this connexion (sic) took over the Griesheim patents and technique for polyvinyl acetate manufacture... Bayer became the concern's principal manufacturer of the azo-group of dyes... Badische became the specialist in high-pressure synthesis in all its aspects" (Haber 1971, pp. 285-86). ${ }^{22}$

Estimates with the restricted sample of patents until 1924 confirm that firms whose patents had been licensed patented more in fields with licensing after 1918. Baseline estimates indicate that firms whose patents had been licensed applied for 0.16 additional patents after 1918 in fields with licensing (Table 4, column 3, p-value 0.002). Compared with an average of 0.46 patents per field and year until 1918 for firms with licensed patents, this implies a 35 percent increase. Regressions with field-specific pre-trends indicate a slightly larger increase of 0.17

\footnotetext{
${ }^{21}$ Also see Aftalion (2001, p. 138): "The new giant had a workforce of 67,000 people including 1,000 chemists, and accounted for one third of Germany's chemical industry sales."

${ }^{22}$ In the main specifications, we assign patents by IG Farben to the original six firms according to the pre-existing distribution of patents between 1910 and 1914 across firms and technology fields (Appendix Table A7). This approach allows us to include IG Farben in the inventor-level analysis but it assumes that the distribution of patenting remained stable after the 1924 .
} 
additional patents per year after 1918 (Table 4, column 4, p-value 0.002), which implies a 37 percent increase.

Excluding data after 1924 may, however, lead us to underestimate firms' response to compulsory licensing, if compulsory licensing influences invention with some delay. For US inventors, the strongest increase in patenting occurred six years after the first licenses were issued, which is consistent with a prolonged period of learning (Moser and Voena 2012, p. 409). For example, Du Pont's early runs of indigo blue turned out green (Hounshell and Smith 1988, p.90). If German inventors also responded to compulsory licensing with some delay, regressions that drop years after 1924 underestimate the effects of compulsory licensing.

\section{B. Renewal Decisions to Proxy for Patent Quality}

Regressions with renewal data imply a smaller, albeit substantial increase. German firms applied for 0.29 additional renewed patents after 1918 in fields in which their patents had been licensed (Table 4, column 5, p-value $<0.001)$. Relative to an average of 0.39 renewed patents per field and year until 1918 for firms with licensed patents, this implies a 74 percent increase. Estimates with field-specific pre-trends indicate that German firms applied for 0.30 additional renewed patents in fields with licensing (Table 4, column 6, p-value < 0.001), which implies a 77 percent increase. Regressions with a separate trend for firms with licensing indicate that German firms applied for 0.29 additional renewed patents per year in fields with licensing; this implies a 74 percent increase (not reported).

In sum, individual-level patent data indicate that compulsory licensing led firms whose patents had been licensed to patent more in fields with licensing. One potential mechanism for 
this change is an increase in the threat of competition in fields in which competition was weak before licensing. We examine this mechanism in the following section.

\section{Changes In COMPETITION}

As an antitrust remedy, compulsory licensing is used as a mechanism to increase competition and encourage innovation (e.g., Chien 2003). The relationship between competition and innovation, however, is theoretically ambiguous, and depends on the specific circumstances under which government policies encourage or discourage innovation.

\section{A. Theoretical Predictions on Competition and Innovation}

Arrow (1962) shows that, if patents create exclusive monopoly rights to inventions, incentives to innovate are smaller for a monopolist who faces no (actual or potential) competition, compared with a competitive firm. For the monopolist, the stream of rents from an invention replaces an existing stream of rents. For a competitive firm, there are no existing streams of rents, so that incentives to innovate are higher for the competitive firm than for the monopolist. ${ }^{23}$ In contrast with these predictions, Schumpeter (1934 and 1942) argues that large firms and a relatively concentrated market structure can promote invention by improving the

\footnotetext{
${ }^{23}$ Consistent with these predictions, Acs and Audretsch (1988) have documented a positive correlation between industries with lower levels of concentration and invention, using data on 8,074 US manufacturing inventions listed in 1982 trade journals. Nickell (1996) presents evidence on 670 UK manufacturing firms between 1972 and 1986, which suggests that competition (measured by the number of competitors or by lower levels of rents) is associated with significantly higher rates of total factor productivity growth. Blundell et al.'s (1999) analysis of 340 manufacturing firms listed on the London Stock Exchange between 1972 and 1982 indicates that industries with lower levels of concentration produced more "technologically significant and commercially important" inventions.
} 
ability of innovators to capture the returns from $\mathrm{R} \& \mathrm{D} .{ }^{24}$ In the context of intellectual property, Schumpeter's hypothesis implies that patents can encourage invention by granting temporary monopoly rights to inventors, which enable them to recover costly investments in $R \& D$ (Scotchmer 2004, pp. 36-39). This suggests that compulsory licensing can discourage invention by weakening the effectiveness of intellectual property and by reducing inventors' ability to recover investments in $R \& D$.

Aghion et al. (2001, 2005) reconcile these predictions through an inverted U-shaped relationship between competition and invention. ${ }^{25}$ At low levels of competition, an increase in competition can encourage invention by encouraging incumbents to invest in R\&D to "escape" competition. At high levels of competition, an increase in ("neck-and-neck") competition discourages invention by further reducing post-invention rents. ${ }^{26}$ In the following paragraphs we use data on German patents to examine these predictions in the context of compulsory licensing.

\section{B. Increased Entry into Fields with Licensing}

Patent data confirm a significant differential increase of US invention in research fields with licensing (Data Section II.D, Figure 1). These results are consistent with US patent data, which indicate that US inventors begun to patent more in fields with licensing after 1918 (Moser

\footnotetext{
${ }^{24}$ Goettler and Gordon (2011) confirm these predictions with estimates of a dynamic oligopoly model for the durable goods microprocessor industry; their estimates imply that the rate of innovation in product quality would be 4.2 percent higher if IBM was a monopolist.

${ }^{25}$ Schmidt (1997) predicts an inverted U by incorporating bankruptcy: Competition increases the risk of bankruptcy, which encourages managers to innovate to preserve their jobs, but also reduces returns from cost-saving inventions by reducing demand for each firm. At high levels of competition, the latter effect dominates so that investments in $R \& D$ peak at an intermediate level of competition.

${ }^{26}$ These predictions are confirmed in a data set of UK patents issued to 311 firms between 1973 and 1994. Patenting increases in response to shifts towards competition at low levels of competition, but declines when pre-existing levels of competition are high (Aghion et al. 2005).
} 
and Voena 2012). This increased presence of US inventors created a threat of competition, which - according to Arrow (1962) - may have encouraged incumbent patentees to invent more.

Moreover, inventor-level analyses of changes in patenting reveal a large increase after 1918 in the number of German firms that were active in fields with licensing. Until 1918, an average of 2.29 German firms without licensed patents produced patents in fields with licensing; after 1918 this number increased by 70 percent to 3.90 firms (Table 5). By comparison, the average number of German firms without licensed patents that patented in fields without licensed patents increased by 23 percent, from 1.22 to 1.50 . After 1918, entrants without previous patents in fields with licensing accounted for 5,065 of 12,852 German-owned (39 percent) in fields with licensing.

One example of a firm that entered fields with licensing is the Deutsche Gold und SilberScheide-Anstalt (Degussa). Until 1918, Degussa applied for a total of 58 patents across 10 fields of chemical inventions, including 54 patents in 8 fields with licensing. After 1918, Degussa applied for a total of 147 patents, including 83 patents in the same 8 fields with licensing, 24 in fields without licensing, and 50 patents in 12 fields with licensing, in which Degussa had not patented until 1918.

To investigate whether the observed increase in patenting in fields with licensing was driven by firms that switched into fields with licensing from other fields of chemical research, we measure the share of patents in fields with licensing by firms with previous patents in other fields of chemicals (switchers) and firms without previous patents (entrants into chemical research). This analysis shows that the increase in patenting by entrants in fields with licensing was driven 
primarily by entrants without previous patents for chemicals. Entrants without previous patents in any field of chemical research account for 2,898 of 5,065 patents (57 percent). ${ }^{27}$

\section{B. Differential Effects Across Low and High Levels of Competition}

Individual-level patent data also enable us to perform a basic test of the inverse-U-shaped relationship between competition and invention (Aghion et al. 2005). Although market share data are not available at the fine-grained level of 212 research fields that we use in our analysis, we can create an alternative measure of competition through a Herfindahl-Hirshman index (HHI) of patents per technology field and year:

$$
\mathrm{HHI}_{\mathrm{ct}}=\frac{\left(\sum_{i} p_{i c t}^{2}\right)-1 / F_{c t}}{1-1 / F_{c t}}
$$

where $p_{i c t}$ is firm $i$ 's share of total patents in field $c$ and year $t$, and $F_{c t}$ measures the number of patent-active firms in field $c$ and year $t$. Comparisons of patent counts for 3,265 field-year pairs show that most research fields are relatively competitive: Two-thirds of all field-year pairs have an HHI of 0.1 or less (Figure 2). Similar to plots of patent counts across UK industries in Aghion et al. (2005), the data are also broadly consistent with an inverted U-shaped relationship between competition and invention. $^{28}$

\footnotetext{
${ }^{27}$ Patents per year by firms without pre-1919 patents in other fields of chemical research increased from 1.45 in 1919 to 2.96 in 1924 and 2.91 in 1929 (Appendix Figure A7). By comparison, the average number of patents by entrants with pre-1919 patents increased from 1.28 in 1919 to 1.85 in 1924 and 1.82 in 1929.

${ }^{28}$ Figure 2 is most similar to Figure 1 in Aghion et al. 2005, which plots patents per industry and year against (1-) the Lerner index as a measure for the intensity of competition. Estimates with the $\mathrm{HHI}$ and the concentration ratio $(\mathrm{C} 4$, not reported) are also consistent with Levin, Cohen, and Mowery's (1985) findings that competition and invention are positively correlated up to the $5^{\text {th }}$ and $6^{\text {th }}$ decile of the C4 in FTC line of business data. Levin et al. (1985) find that this correlation disappears with controls for variation across industries in the effectiveness of mechanisms to appropriate the returns from R\&D. Our analysis investigates variation in competition within
} 
To compare the effect of compulsory licensing across fields with low and high levels of pre-existing competition, we re-estimate the baseline specification (equation 2) with an additional interaction term between the difference-in-differences estimator and a set of indicator variables for deciles of the HHI across all years until 1918:

(6) patents $_{c t}=\alpha+\Sigma_{\mathrm{d}} \beta_{\mathrm{d}} \bullet$ field $w$ licensed patents $\boldsymbol{~}_{c} \bullet$ pre-1919 HHI decile $_{d} \bullet$ post $_{t}$ $+\Sigma_{\mathrm{d}} \gamma_{\mathrm{d}} \bullet$ pre-1919 HHI decile $_{d} \bullet$ post $_{t}+\zeta_{\mathrm{l}} \bullet$ field $w$ licensed patents $_{c} \bullet$ post $_{t}$ $+\zeta_{2} \cdot$ patents by US inventors $s_{c t}+\zeta_{3} \cdot$ patents by other foreign inventors $s_{c t}+\delta_{t}$ $+\theta_{c}+\Sigma_{\mathrm{c}} \phi_{c} \cdot$ field $_{c} \bullet \operatorname{preTWEA}_{t} \bullet t+\varepsilon_{c t}$

where the $5^{\text {th }}$ and $6^{\text {th }}$ decile of the HHI are the omitted categories. Estimates increase from 8.22 fewer patents for the $10^{\text {th }}$ decile (Appendix Figure A8, p-value of 0.26) to 14.74 additional patents for the $7^{\text {th }}$ decile (p-value of 0.11 ). Estimates are close to zero for the $4^{\text {th }}$ to the $1^{\text {st }}$ decile of the HHI. These estimates suggest that the observed increase in patenting was driven by technologies in which patenting was relatively concentrated before 1919 .

\section{CONCLUSIONS}

This paper has used a new data set of 79,591 chemical patents in Germany between 1900 and 1930 to examine the effects of compulsory licensing under the WWI Trading with the Enemy Act on German invention. Under the TWEA, all German-owned US patents became subject to compulsory licensing in 1919 . We find that compulsory licensing encouraged, rather than discouraged invention in Germany. German inventors produced 28 percent more patents after 1918 in research fields with licensing. Intent-to-treat regressions and instrumental variable

chemicals in the early $20^{\text {th }}$ century, when patents had become an effective mechanism to appropriate the returns from R\&D in chemicals (Moser 2012). 
regressions, which use fields with confiscations as an instrument for fields with licensing, suggest that OLS estimates underestimate the effect of compulsory licensing on German patents.

An analysis of high-quality patents indicates a slightly smaller increase in patenting. This suggests that some of the observed increase in patenting may have been due to an increase in lower quality strategic patents. Estimates, however, remain large and statistically significant, and imply a 17 percent increase in high-quality patents.

Inventor-level analyses of patent data reveal a significant increase in the number of research-active firms in research fields with licensing. Nearly 40 percent of all patents after 1918 in fields with licensing were by firms without pre-1918 patents in these fields. Among entrants into fields with licensing, firms without previous patents in any other fields of chemicals produced more patents in fields with licensing after 1918 compared with firms that had been active in other fields of chemical research before 1918. We also find that German firms whose patents had been licensed produced more patents after 1918 in fields in which their patents had been licensed. Taken together, these results indicate that compulsory licensing can promote invention by encouraging competitors to enter fields with licensing, which increases the threat of competition for incumbent inventors and motivates them to invest more in R\&D.

In the early $20^{\text {th }}$ century and today, industries that are most affected by compulsory licensing tend to be relatively concentrated. In 2013, for example, therapies by Gilead, Johnson \& Johnson, and Brystol Myers dominated the market for HIV drugs. Gilead's Truvada and related drugs accounted for $\$ 9$ billion in sales, Brystol-Myers Sustiva generated $\$ 3.6$ billion, and Ruveda, which combines Gilead's drug Viread and Emtriva, recorded \$3.1 billion in sales, while other drugs sold substantially less (Campbell 2014). Our findings suggest that compulsory licensing can encourage invention in these industries. In fact, we find that compulsory licensing 
was particularly effective at promoting invention in fields that were ex ante more concentrated, and less effective in fields that were competitive already.

It is, however, important to note that the benefits of compulsory licensing depend on the credibility with which national governments can commit to invoke it exclusively in cases of emergencies. Triggered by Germany's military aggression, the 1919 Trading-with-the-Enemy Act was at the time perceived as a one-shot event. We find that incumbent inventors responded by investing heavily in $R \& D$ to escape competition with new entrants. Similar to other types of public policies, such as flood control measures, monetary policy, and capital taxation (Kydland and Prescott 1977, Fischer 1980), compulsory licensing is subject to dynamic inconsistency, and firms may invest less in R\&D if they expect repeated episodes of compulsory licensing. ${ }^{29} \mathrm{We}$ conclude that compulsory licensing can promote innovation - if governments can credibly commit to using it only in exceptional cases of emergencies.

\section{REFERENCES}

Acs, Zoltan, and David Audretsch. 1988. "Innovation in Large and Small Firms: an Empirical Analysis.” American Economic Review 78 (4): 678-90.

Aftalion, Fred. 2001. A History of the International Chemical Industry. Translated

by Otto Benfey. Philadelpia: University of Pennsylvania Press.

Aghion, Philippe, Christopher Harris, Peter Howitt, and John Vickers. 2001.

“Competition, Imitation and Growth with Step-by-step Innovation." Review of

\footnotetext{
${ }^{29}$ In fact, Kydland and Prescott (1977, p. 477) cite patent policy as an example for dynamic inconsistency: "Given that resources have been allocated to inventive activity which resulted in a new product or process, the efficient policy is not to permit patent protection. For this example, few would consider this optimal-control theory solution as being reasonable. Rather, the question would be posed in terms of the optimal patent life (see, e.g., Nordhaus 1969), which takes into consideration both the incentive for inventive activity provided by patent protection and the loss in consumer surplus that results when someone realizes monopoly rents."
} 
Economic Studies 68: 467-92.

Aghion, Philippe, Nick Bloom, Richard Blundell, Rachel Griffith, and Peter Howitt. 2005. "Competition and Innovation: An Inverted-U Relationship." Quarterly Journal of Economics 120 (2): 701-28.

Alien Property Custodian. 1919. A Detailed Report by the Alien Property Custodian of All Proceedings Had by Him under the Trading with the Enemy Act during the Calendar year 1918 and to the Close of Business on February 15, 1919.Washington, DC: Government Printing Office.

Arrow, Kenneth. 1962. "Economic Welfare and the Allocation of Resources for invention." in Richard Nelson (ed.), The Rate and Direction of Inventive Activity. Economic and Social Factors. Cambridge, MA: National Bureau of Economic Research.

Bidwell, Robin L. 1970. Currency Conversion Tables: A Hundred Years of Change, London: Rex Collings. 22-24.

Blundell, Richard, Rachel Griffith, and John Van Reenen. 1999. "Market Share, Market Value and Innovation in a Panel of British Manufacturing Firms," Review of Economic Studies 66: 529-54.

Bond, Eric and Kamal Saggi. 2014 "Compulsory Licensing, Price Controls, and Access to Patented Foreign Products," Journal of Development Economics 109: 217-228, 2014.

Campbell, Todd. 2014. "Can Gilead Dominate the HIV Drug Market Again in 2014?” The Motley Fool, March 12, 2014.

Chien, Colleen. 2003. "Cheap Drugs at What Price to Innovation: Does the Compulsory Licensing of Pharmaceuticals Hurt Innovation?” Berkeley Technology Law Journal. 
Cohen, Wesley M., Richard R. Nelson, and John P. Walsh. 2000. "Protecting Their Intellectual Assets: Appropriability Conditions and Why U.S. Manufacturing Firms Patent (or Not).” NBER Working Paper No 7552.

Deutsches Patentamt. 1914, 1915, and 1918. Blatt fuer das Patent-, Muster- und Zeichenwesen, volumes 20, 21, and 24; Heymann: Berlin.

Fischer, Stanley. 1980. Rational Expectations and Economic Policy. Chicago: University of Chicago Press.

Goettler, Ronald L. and Brett R. Gordon. 2011. "Does AMD Spur Intel to Innovate More?" Journal of Political Economy vol. 119(6), pp. 1141-1200.

Green, Jerry, and Suzanne Scotchmer. 1990. "Novelty and Disclosure in Patent Law." The Rand Journal of Economics, vol. 21, 131-146.

Griliches, Zvi. 1990. "Patent Statistics as Economic Indicators: A Survey." Journal of Economic Literature 28 (4): 1661-1707.

Haber, Ludwig F. 1971. The Chemical Industry, 1900-1930, International Growth and Technological Change. Oxford: Clarendon Press.

Hall, Bronwyn H. and Rosemarie Ham Ziedonis. 2001. “The Patent Paradox Revisited: An Empirical Study of Patenting in the U.S. Semiconductor Industry, 1979-1995." The RAND Journal of Economics 32 (1): 101-128.

Handbuch der Deutschen Aktiengesellschaften. Issue 1911/12, vol. I - II, Berlin: Hoppenstedt.

Harhoff, Dietmar, Francis Narin, Frederic M. Scherer, and Katrin Vopel. 1999. "Citation Frequency and the Value of Patented Inventions." Review of Economics and Statistics 81 (3): 511-15. 
Haynes, Williams. 1945. American Chemical Industry - The World War I period 1912-1922. New York: D. Van Nostrand Company.

Hounshell, David A., and John Kenly Smith, Jr. 1988. Science and Corporate Strategy: Du Pont R\&D, 1902-1980. Cambridge, UK: Cambridge University Press.

Kydland, Finn. E., and Edward C. Prescott. 1977. "Rules Rather than Discretion: The Inconsistency of Optimal Plans.” The Journal of Political Economy 85 (3): 473-92.

Lanjouw, Jean O., Ariel Pakes, and Jonathan Putnam. 1998. "How to Count Patents and Value Intellectual Property: The Uses of Patent Renewal and Application Data." The Journal of Industrial Economics 46 (4): 405-32.

Levin, Richard C., Wesley M. Cohen, and David C. Mowery. 1985. “R\&D Appropriability, Opportunity, and Market Structure: New Evidence on Some Schumpeterian Hypotheses.” American Economic Review 75(2): pp. 20-4.

Levin, Richard C., Alvin K. Klevorick, Richard Nelson, and Sidney Winter. 1987. “Appropriating the Returns from Industrial Research and Development." Brookings Papers on Economic Activity, 18 (3): 783-832.

Moser, Petra. 2003. "How do Patent Laws Influence Innovation? Evidence from Nineteenth-Century World's Fairs.” NBER Working Paper 9909.

Moser, Petra. 2005. "How do Patent Laws Influence Innovation? Evidence from Nineteenth-Century World's Fairs.” American Economic Review 95 (4): 12141236. 
Moser, Petra. 2011. "Do Patents Weaken the Localization of Innovations? Evidence from World's Fairs". The Journal of Economic History. Vol. 71. Issue 02. June 2011, pp. 363-382. Moser, Petra. 2012. "Innovation without Patents." Journal of Law and Economics, 2012, Vol. 55. No. 1, pp. 43-74.

Moser, Petra, and Alessandra Voena. 2012. "Compulsory Licensing: Evidence from the Trading with the Enemy Act." American Economic Review 102 (1): 396427.

Moser, Petra, Alessandra Voena, and Fabian Waldinger. 2014. "GermanJewish Émigrés and US Invention.” American Economic Review 104(10): 3222-55.

Moser, Petra and Joerg Ohmstedt, and Paul Rhode. 2014. "Patent Citations and the Size of the Inventive Step. Evidence from Hybrid Corn."

Murray, Fiona, Philippe Aghion, Mathias Dewatripont, Julian Kolev, and Scott Stern. 2009. "Of Mice and Academics: Examining the Effect of Openness on Innovation.” NBER Working Paper No. 14819.

Nickell, Steven. 1996. "Competition and Corporate Performance." Journal of Political Economy 104: 724-46.

Nordhaus, William D. Invention Growth and Welfare: A Theoretical Treatment of Technical Change. Cambridge. Mass: MIT Press, 1969

Reichspatentamt. 1901-1933. Verzeichnis der im Vorjahre Erteilten Patente.

Reichspatentamt. 1912. Systematische Übersicht der vom 1. Januar bis 31. Dezember 1912 in die Patentrolle eingetragenen Patente.

Richter, Ralf, and Jochen Streb. 2011. "Catching-Up and Falling Behind: Knowledge Spillover from American to German Machine Toolmakers." The 
Journal of Economic History 71(04): 1006-1031.

Schankerman, Mark, and Ariel Pakes. 1986. "Estimates of the Value of Patent Rights in European Countries During the post-1950 Period." The Economic Journal 96 (384): 1052-1076.

Schmidt, Klaus M. 1997. "Managerial Incentives and Product Market Competition." The Review of Economic Studies 64(2): 191-213.

Schumpeter, Joseph A. 1934. The Theory of Economic Development. Cambridge, MA: Harvard University Press.

Schumpeter, Joseph A. 1942. Capitalism, Socialism, and Democracy. New York: Harper and Brothers.

Scotchmer, Suzanne. 1991. "Standing on the Shoulders of Giants: Cumulative Research and the Patent Law." Journal of Economic Perspectives 5(1): 29-41.

Scotchmer, Suzanne. 2004. Innovation and Incentives. Cambridge, MA: MIT Press. Shapiro, Carl. 2001. "Navigating the Patent Thicket: Cross Licenses, Patent Pools, and Standard-Setting." Chapter 4 in Adam B. Jaffe, Josh Lerner, and Scott Stern, editors. Innovation Policy and the Economy, volume 1, Cambridge: MIT Press. $119-150$.

Steen, Kathryn. 2001. "Patents, Patriotism, and 'Skilled in the Art' USA v. The Chemical Foundation, Inc., 1923-1926.” Isis 92(1): 91-122.

Trajtenberg, Manuel. 1990. “A Penny for Your Quotes: Patent Citations and the Value of Innovations.” RAND Journal of Economics 21 (1): 172-187.

Williamson, Samuel H. 2014. "Seven Ways to Compute the Relative Value of a US Dollar Amount, 1790 to Present.” www.measuringworth.com/uscompare. 
TABLE 1 - GPO PATENTS BY GERMAN INVENTORS PER FIELD AND YEAR

\begin{tabular}{|c|c|c|c|c|c|}
\hline \multicolumn{6}{|c|}{ PANEL A: RESEARCH FIELDS WITH AND W/O LICENSED PATENTS } \\
\hline & \multicolumn{2}{|c|}{$\begin{array}{l}\text { Fields with } \\
\text { licensed patents }\end{array}$} & \multicolumn{2}{|c|}{$\begin{array}{l}\text { Fields without } \\
\text { licensed patents }\end{array}$} & \multirow[t]{2}{*}{ Difference } \\
\hline & $\mathrm{N}$ & Mean & $\mathrm{N}$ & Mean & \\
\hline \multicolumn{6}{|l|}{ All patents } \\
\hline $1900-1918$ & 101 & $\begin{array}{l}10.77 \\
(1.31)\end{array}$ & 111 & $\begin{array}{c}5.05 \\
(0.58)\end{array}$ & $\begin{array}{c}5.72 \\
(1.43)\end{array}$ \\
\hline $1919-1930$ & 101 & $\begin{array}{l}16.49 \\
(2.47)\end{array}$ & 111 & $\begin{array}{c}5.54 \\
(0.95)\end{array}$ & $\begin{array}{l}10.95 \\
(2.64)\end{array}$ \\
\hline \multicolumn{6}{|c|}{ Patents renewed $\geq 5$ years } \\
\hline 1900-1918 & 101 & $\begin{array}{c}6.28 \\
(0.84)\end{array}$ & 108 & $\begin{array}{c}2.56 \\
(0.30)\end{array}$ & $\begin{array}{c}3.72 \\
(0.89)\end{array}$ \\
\hline 1919-1930 & 101 & $\begin{array}{l}8.05 \\
(1.29)\end{array}$ & 108 & $\begin{array}{c}2.28 \\
(0.38)\end{array}$ & $\begin{array}{c}5.77 \\
(1.35)\end{array}$ \\
\hline \multicolumn{6}{|c|}{ PANEL B: FIRMS WITH AND W/O LICENSED PATENTS } \\
\hline & \multicolumn{2}{|c|}{$\begin{array}{l}\text { Firms with } \\
\text { licensed patents }\end{array}$} & \multicolumn{2}{|c|}{ Other firms } & Difference \\
\hline & $\mathrm{N}$ & Mean & $\mathrm{N}$ & Mean & \\
\hline \multicolumn{6}{|l|}{ All patents } \\
\hline $1900-1918$ & 50 & $\begin{array}{c}0.46 \\
(0.10)\end{array}$ & 4,764 & $\begin{array}{c}0.05 \\
(0.01)\end{array}$ & $\begin{array}{c}0.41 \\
(0.01)\end{array}$ \\
\hline 1919-1930 & 50 & $\begin{array}{c}0.94 \\
(0.23)\end{array}$ & 4,764 & $\begin{array}{c}0.10 \\
(0.01)\end{array}$ & $\begin{array}{c}0.84 \\
(0.01)\end{array}$ \\
\hline \multicolumn{6}{|c|}{ Patents renewed $\geq 5$ years } \\
\hline 1900-1918 & 47 & $\begin{array}{c}0.39 \\
(0.08)\end{array}$ & 2,933 & $\begin{array}{c}0.05 \\
(0.01)\end{array}$ & $\begin{array}{c}0.34 \\
(0.01)\end{array}$ \\
\hline 1919-1930 & 47 & $\begin{array}{c}0.66 \\
(0.16) \\
\end{array}$ & 2,933 & $\begin{array}{r}0.09 \\
(0.01) \\
\end{array}$ & $\begin{array}{c}0.57 \\
(0.01) \\
\end{array}$ \\
\hline
\end{tabular}

Notes: Data include 58,691 German patents by German inventors with application dates between January 1, 1900 and December 31, 1930. Patents renewed $\geq 5$ years are 30,017 patents, for which inventors paid renewal fees for 5 years or more. Fields with licensed patents cover 101 research fields in which at least 1 German-owned US patent was licensed. Fields without licensed patents cover 111 remaining research fields within chemicals without licensed patents. Standard errors are clustered at the level of research fields (Panel A) or at the firm level (Panel B). 
TABle 2 - OLS, DePendent Variable Is PATENTS Per Field AND Year

\begin{tabular}{|c|c|c|c|c|c|c|c|c|}
\hline & \multicolumn{6}{|c|}{$\begin{array}{l}\text { All Patents } \\
(1-6)\end{array}$} & \multicolumn{2}{|c|}{$\begin{array}{c}\text { Patents renewed } \geq 5 y \\
(7-8)\end{array}$} \\
\hline & $(1)$ & $(2)$ & $(3)$ & $(4)$ & $(5)$ & (6) & $(7)$ & $(8)$ \\
\hline Field with licensed patents*post & $\begin{array}{l}2.968 * * * \\
(0.915)\end{array}$ & $\begin{array}{l}5.219 * * * \\
(1.535)\end{array}$ & $\begin{array}{l}5.317 * * * \\
(1.427)\end{array}$ & $\begin{array}{l}5.017 * * * \\
(1.394)\end{array}$ & & & $\begin{array}{l}1.092 * * \\
(0.466)\end{array}$ & $\begin{array}{l}2.345^{* * *} \\
(0.720)\end{array}$ \\
\hline Licensed patents $*$ post & & & & & $\begin{array}{l}0.196 * * * \\
(0.069)\end{array}$ & $\begin{array}{l}0.356 * * * \\
(0.113)\end{array}$ & & \\
\hline Licensed patents ${ }^{2} *$ post & & & & & $\begin{array}{l}-0.000 * * * \\
(0.000)\end{array}$ & $\begin{array}{l}-0.001 * * * \\
(0.000)\end{array}$ & & \\
\hline Patents by US inventors & $\begin{array}{l}0.859 * * * \\
(0.142)\end{array}$ & & $\begin{array}{l}0.700 * * * \\
(0.136)\end{array}$ & $\begin{array}{l}0.857 * * * \\
(0.142)\end{array}$ & $\begin{array}{l}0.815 * * * \\
(0.142)\end{array}$ & $\begin{array}{l}0.667 * * * \\
(0.131)\end{array}$ & $\begin{array}{l}0.817 * * * \\
(0.149)\end{array}$ & $\begin{array}{l}0.687 * * * \\
(0.163)\end{array}$ \\
\hline Patents by other foreign inventors & $\begin{array}{l}1.503 * * * \\
(0.228)\end{array}$ & & $\begin{array}{l}1.353 * * * \\
(0.229)\end{array}$ & $\begin{array}{l}1.500 * * * \\
(0.228)\end{array}$ & $\begin{array}{l}1.376^{* * *} \\
(0.153)\end{array}$ & $\begin{array}{l}1.233 * * * \\
(0.156)\end{array}$ & $\begin{array}{l}1.194 * * * \\
(0.186)\end{array}$ & $\begin{array}{l}1.136 * * * \\
(0.205)\end{array}$ \\
\hline \multicolumn{9}{|c|}{ Standard errors (in parentheses) are clustered at the level of fields, $* * * p<0.01, * * \mathrm{p}<0.05, * \mathrm{p}<0.1$} \\
\hline Mean in fields w licensed patents 1900-18 & 10.77 & 10.77 & 10.77 & 10.77 & 10.77 & 10.77 & 6.28 & 6.28 \\
\hline Field-specific pre-trends & No & No & Yes & No & No & Yes & No & Yes \\
\hline Pre-trend for fields with licensing & No & No & No & Yes & No & No & No & No \\
\hline Field fixed effects & Yes & Yes & Yes & Yes & Yes & Yes & Yes & Yes \\
\hline Year fixed effects & Yes & Yes & Yes & Yes & Yes & Yes & Yes & Yes \\
\hline $\mathrm{N}$ & 6,572 & 6,572 & 6,572 & 6,572 & 6,572 & 6,572 & 6,479 & 6,479 \\
\hline
\end{tabular}

Notes: Data include all 79,591 patents on chemicals with application years between 1900 and 1930. Data on renewal decisions are collected from the Annual Reports of the German Patent Office between 1901 and 1942. The indicator variable field with licensed patents equals 1 for 101 research fields, in which at least 1 US patent was licensed. The indicator variable post equals 1 for all years after 1918. The variable licensed patents measures the number of patents that became subject to licensing. Patents by US inventors controls for the number of patents issued to residents of the United States in field $c$ and year $t$; patents by other foreign inventors controls for patents issued to residents of other foreign countries. 
TABLE 3 - INTENT-TO-TREAT AND INSTRUMENTAL VARIABLE REGRESSIONS,

DEPENDENT VARIABLE IS PATENTS PER FIELD AND YEAR

\begin{tabular}{|c|c|c|c|c|c|c|c|}
\hline & \multirow{2}{*}{\multicolumn{3}{|c|}{ Intent to Treat (1-3) }} & \multicolumn{4}{|c|}{ Instrumental Variables (4-7) } \\
\hline & & & & \multicolumn{2}{|c|}{ First stage } & \multicolumn{2}{|c|}{ IV } \\
\hline & $(1)$ & $(2)$ & $(3)$ & (4) & $(5)$ & (6) & $(7)$ \\
\hline Field with confiscated patents $*$ post & $\begin{array}{l}2.359 * * * \\
(0.808)\end{array}$ & $\begin{array}{l}4.474 * * * \\
(1.324)\end{array}$ & $\begin{array}{l}4.264 * * * \\
(1.331)\end{array}$ & $\begin{array}{l}0.582 * * * \\
(0.014)\end{array}$ & $\begin{array}{l}0.585 * * * \\
(0.014)\end{array}$ & & \\
\hline Field with licensed patents * post & & & & & & $\begin{array}{l}4.050 * * * \\
(0.840)\end{array}$ & $\begin{array}{l}7.652^{* * *} \\
(1.213)\end{array}$ \\
\hline Patents by US inventors & $\begin{array}{l}0.886 * * * \\
(0.144)\end{array}$ & $\begin{array}{l}0.726 * * * \\
(0.136)\end{array}$ & $\begin{array}{l}0.884 * * * \\
(0.144)\end{array}$ & $\begin{array}{l}0.010 * * * \\
(0.002)\end{array}$ & $\begin{array}{l}0.006 * * * \\
(0.002)\end{array}$ & $\begin{array}{l}0.845 * * * \\
(0.086)\end{array}$ & $\begin{array}{l}0.683 * * * \\
(0.086)\end{array}$ \\
\hline Patents by other foreign inventors & $\begin{array}{l}1.517 * * * \\
(0.231)\end{array}$ & $\begin{array}{l}1.370 * * * \\
(0.233)\end{array}$ & $\begin{array}{l}1.517 * * * \\
(0.231)\end{array}$ & $\begin{array}{l}0.006 * * * \\
(0.001)\end{array}$ & $\begin{array}{l}0.004 * * * \\
(0.001)\end{array}$ & $\begin{array}{l}1.495 * * * \\
(0.037)\end{array}$ & $\begin{array}{l}1.340 * * * \\
(0.038)\end{array}$ \\
\hline \multicolumn{8}{|c|}{ Standard errors (in parentheses) are clustered at the level of fields, $* * * \mathrm{p}<0.01, * * \mathrm{p}<0.05, * \mathrm{p}<0.1$} \\
\hline Mean in fields with licensed patents, 1900-18 & 10.77 & 10.77 & 10.77 & & & 10.77 & 10.77 \\
\hline Field-specific pre-trends & No & Yes & No & No & Yes & No & Yes \\
\hline Pre-trend for fields with confiscated patents & No & No & Yes & No & No & No & No \\
\hline Field fixed effects & Yes & Yes & Yes & Yes & Yes & Yes & Yes \\
\hline Year fixed effects & Yes & Yes & Yes & Yes & Yes & Yes & Yes \\
\hline $\mathrm{N}$ & 6,572 & 6,572 & 6,572 & 6,572 & 6,572 & 6,572 & 6,572 \\
\hline
\end{tabular}

Notes: Data include all 79,591 patents for chemicals with application years between 1900 and 1930. The variable field with confiscated patents equals 1 for 171 research fields in which at least 1 US patent was confiscated. The variable field with licensed patents equals 1 for 101 fields, in which at least 1 US patent was licensed. The indicator variable post equals 1 for years after 1918. Patents by US inventors controls for the number of patents issued to residents of the United States in field $c$ and year $t$; patents by other foreign inventors controls for patents issued to residents of other foreign countries. 
TABle 4 - InVEntor-LeVel OLS, DePendent VARIABle is Patents Per Firm, Field, And Year

\begin{tabular}{|c|c|c|c|c|c|c|}
\hline & \multicolumn{2}{|c|}{ All Patents and Years } & \multicolumn{2}{|c|}{$1900-1924$} & \multicolumn{2}{|c|}{ Patents renewed $\geq 5 y$} \\
\hline & $(1)$ & $(2)$ & $(3)$ & $(4)$ & $(5)$ & $(6)$ \\
\hline \multirow[t]{2}{*}{ Field w licensed patents $*$ firm $w$ licensed patents $*$ post } & $0.415 * * *$ & $0.411 * * *$ & $0.155 * * *$ & $0.173 * * *$ & $0.292 * * *$ & $0.300 * * *$ \\
\hline & $(0.134)$ & $(0.134)$ & $(0.051)$ & $(0.055)$ & $(0.073)$ & $(0.074)$ \\
\hline \multirow[t]{2}{*}{ Field w licensed patents $*$ post } & 0.013 & $0.020 * *$ & $0.019 * * *$ & $0.024 * * *$ & 0.012 & $0.016^{*}$ \\
\hline & $(0.008)$ & $(0.009)$ & $(0.006)$ & $(0.008)$ & $(0.008)$ & $(0.010)$ \\
\hline \multirow[t]{2}{*}{ Patents by US firm } & $0.004 * * *$ & $0.003 * * *$ & $0.002 * * *$ & $0.002 * *$ & $0.003 * * *$ & $0.002 * * *$ \\
\hline & $(0.001)$ & $(0.001)$ & $(0.001)$ & $(0.001)$ & $(0.001)$ & $(0.001)$ \\
\hline \multirow[t]{2}{*}{ Patents by other foreign inventors } & $0.006 * * *$ & $0.006 * * *$ & $0.003 * * *$ & $0.003 * * *$ & $0.005 * * *$ & $0.005^{* * *}$ \\
\hline & $(0.002)$ & $(0.002)$ & $(0.001)$ & $(0.001)$ & $(0.002)$ & $(0.002)$ \\
\hline \multirow[t]{2}{*}{ Patents by individual inventors } & $0.002 * * *$ & $0.002 * * *$ & $0.003 * * *$ & $0.003 * * *$ & $0.002 * * *$ & $0.002 * * *$ \\
\hline & $(0.000)$ & $(0.000)$ & $(0.000)$ & $(0.000)$ & $(0.000)$ & $(0.000)$ \\
\hline \multicolumn{7}{|c|}{ Standard errors (in parentheses) are clustered at the level of firms, $* * * p<0.01, * * p<0.05, * p<0.1$} \\
\hline Mean for firms with licensed patents, 1900-18 & 0.46 & 0.46 & 0.46 & 0.46 & 0.46 & 0.46 \\
\hline Field-specific pre-trends & No & Yes & No & Yes & No & Yes \\
\hline Pre-trend for firms with licensing & No & No & No & No & No & No \\
\hline Field fixed effects & Yes & Yes & Yes & Yes & Yes & Yes \\
\hline Firm fixed effects & Yes & Yes & Yes & Yes & Yes & Yes \\
\hline Year fixed effects & Yes & Yes & Yes & Yes & Yes & Yes \\
\hline N (Field-firm-year) & 274,133 & 274,133 & 221,075 & 221,075 & 164,207 & 164,207 \\
\hline
\end{tabular}

Notes: All specifications include controls for firms $w$ licensed patents * post, licensed patents * firms $w$ licensed patents, and field $w$ licensed patents * firms $w$ licensed patents. Data include 30,499 German patents for chemicals by 4,814 unique German firms (8,843 field -firm pairs). The indicator variable firm $w$ licensed patents equals 1 for 50 German firms that saw 1 or more of their US patents licensed under the TWEA. The indicator variable post equals 1 for years after 1918. Field $w$ licensed patents is an indicator variable that equals 1 for 101 German fields, in which at least 1 US patent was licensed. Patents by US inventors controls for patents by US residents in field $c$ and year $t$; patents by other foreign inventors and patents by individuals control for patents to other foreign inventors and individual German inventors, respectively. 
TAble 5 -Firms that were Active Patentees in Germany Per Research Field and Year

\begin{tabular}{|c|c|c|c|c|c|}
\hline & \multicolumn{2}{|c|}{ Fields with licensed patents } & \multicolumn{2}{|c|}{ Fields without licensed patents } & \multirow[t]{2}{*}{ Difference } \\
\hline & $\mathrm{N}$ & Mean & $\mathrm{N}$ & Mean & \\
\hline 1900-1918 & 101 & $\begin{array}{c}2.29 \\
(0.22)\end{array}$ & 111 & $\begin{array}{c}1.22 \\
(0.14)\end{array}$ & $\begin{array}{c}1.07 \\
(0.26)\end{array}$ \\
\hline 1919-1930 & 101 & $\begin{array}{c}3.90 \\
(0.46)\end{array}$ & 111 & $\begin{array}{c}1.5 \\
(0.24)\end{array}$ & $\begin{array}{c}2.40 \\
(0.56)\end{array}$ \\
\hline Difference & & $\begin{array}{c}1.61 \\
(0.32)\end{array}$ & & $\begin{array}{c}0.28 \\
(0.17)\end{array}$ & $\begin{array}{c}1.33 \\
(0.36)\end{array}$ \\
\hline
\end{tabular}

Notes: German firms that applied for at least one successful patent per research field and year; standard errors in parentheses. 4,764 German firms without licensed patents applied for 58,691 patents for chemical inventions between January 1, 1900 and December 31, 1930. 101 fields with licensed patents cover technologies for which at least 1 US patent by another German firm was licensed under the TWEA; 111 fields without licensed patents did not include any licensed patents. 
Figure 1 - US-OWNed PATENTS PER Field ANd APPLICATION YeAR

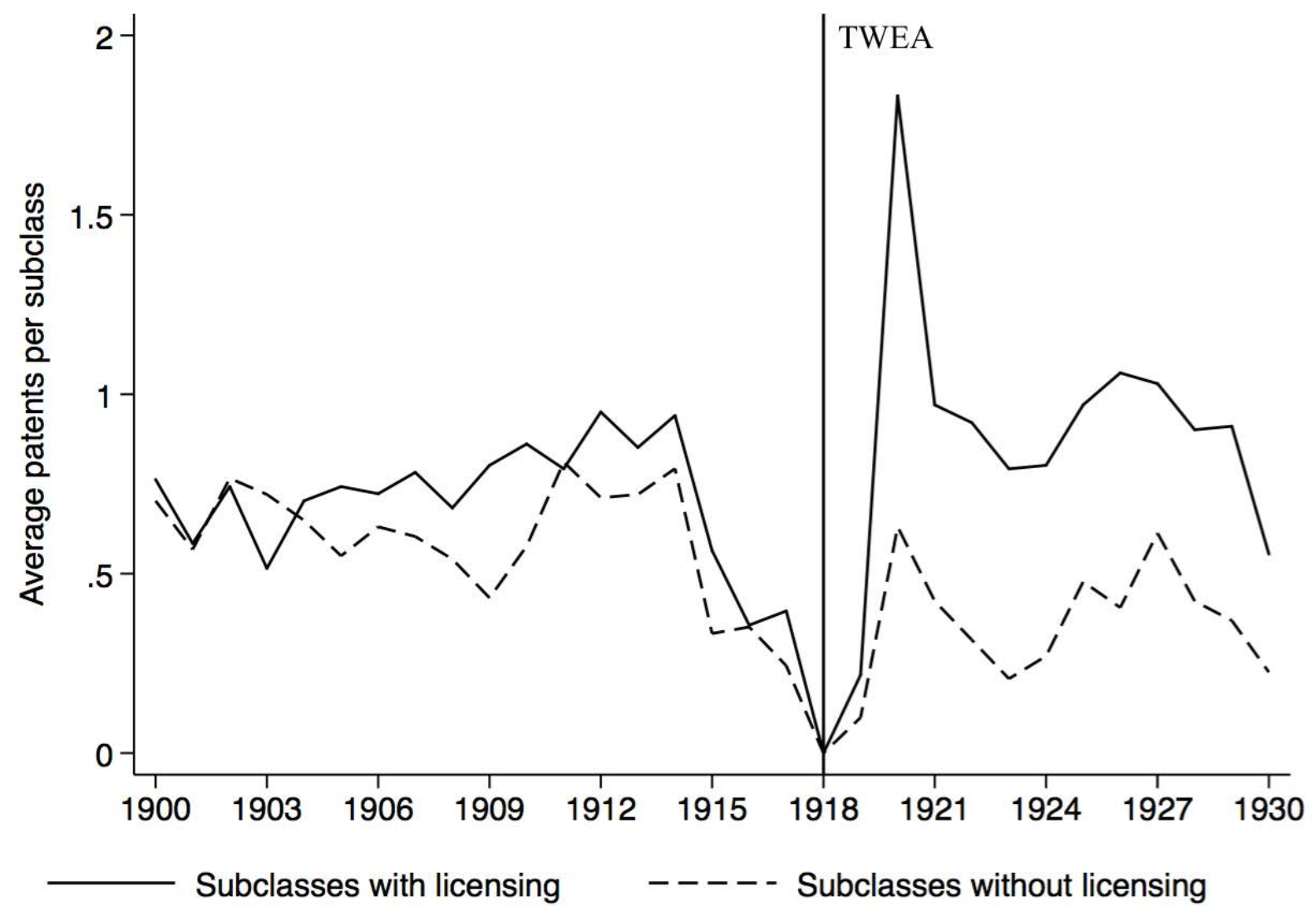

Notes: Data include 4,133 patents issued in Germany to US inventors for application dates between January 11900 and December 31, 1930. We collected these data from lists of issued patents in the Annual Report of the German Patent Office (Verzeichnis der im Vorjahre erteilten Patente) between 1900 and 1932. 101 fields with licensing correspond to technologies in which at least 1 German-owned US patent was licensed to a US firm under the TWEA; 111 other fields without licensing include no licensed patents. 
Figure 2 - INVENTION (PATENTS) ON COMPETITION (1-HHI)

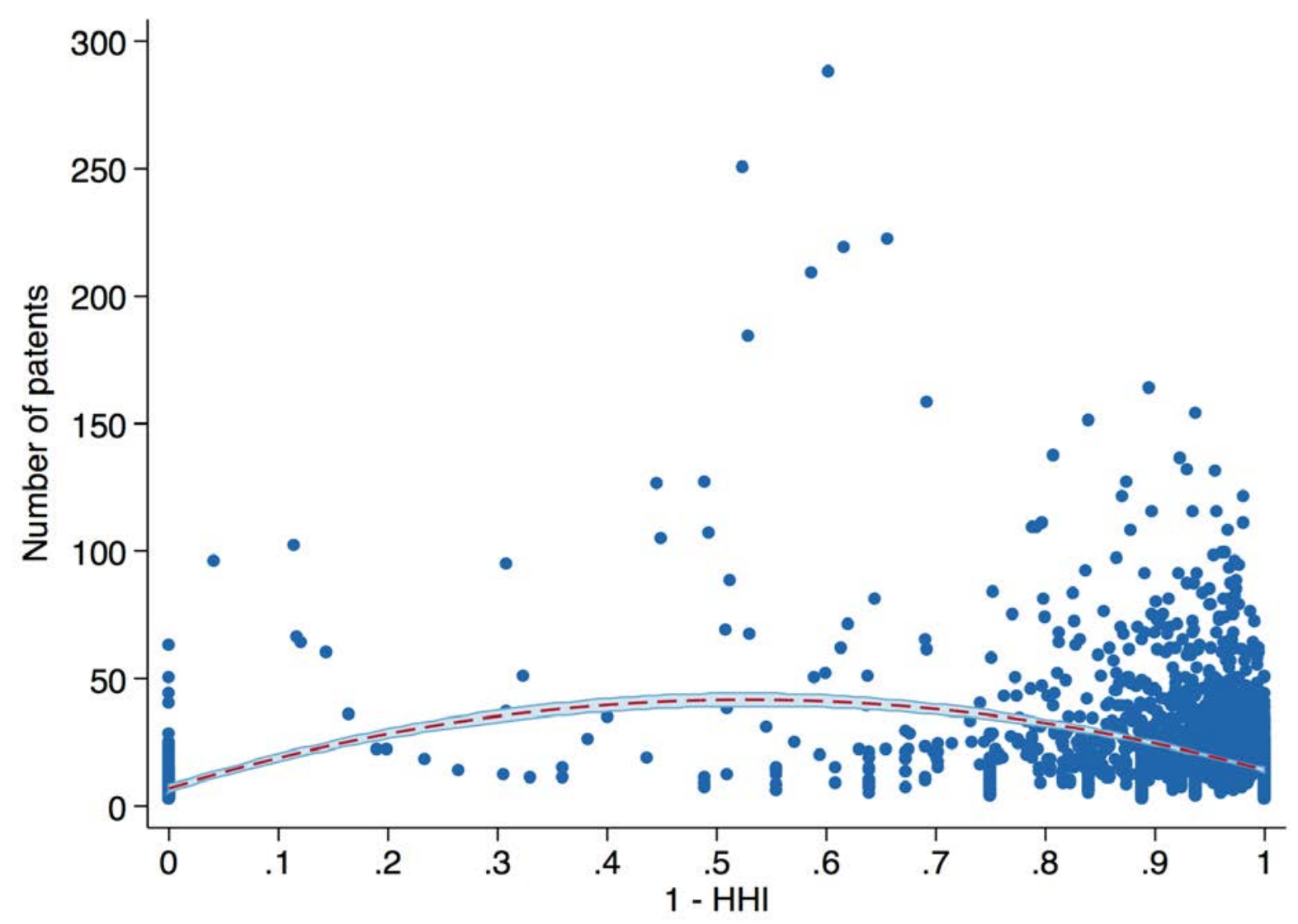

Notes: The figure plots 1-HHI against the total number of German patents per field and year. $\mathrm{HHI}$ is the normalized Herfindahl-Hirschman Index for each field and year and is computed as $\frac{\left(\sum_{i}^{F} p_{i}^{2}-1 / F\right)}{1-1 / F}$, where $p_{i}$ is the patent share of firm $i$ and $F$ is the number of patent-active firms in each field and year. Each observation is a field-year pair for (1-HHI of patents per field, firm and year; patents per field and year). The interrupted red line plots a $2^{\text {nd }}$ order polynomial with 95 percent confidence intervals. Data include all 58,691 German patents for chemicals by German inventors with application years between 1900 and 1930. 
ONLINE APPENDIX Not FOR PUBLICATION 


\section{DATA APPENDIX}

To examine changes in invention, we collected information on all patents issued in Germany between 1900 and 1932 across 212 research fields of chemical inventions. To digitize these data, we first trained a group of typists to read German Fraktur with 99 percent accuracy, at less than one misspelled letter per page. They then collected the complete records of patent issues for chemicals from the Annual Reports of the German Patent Office (Kaiserliches Patentamt, 19001932). We then checked all entries to correct typographical errors in the description of inventions, inventors' names and cities. By this process we were able to collect information on 79,591 German patents issued for chemical processes and products between 1900 and 1932. These patents have application years between 1900 and 1930.

\section{A. Licenses to US Firms}

US authorities confiscated a total of 4,706 German-owned US patents under the TWEA; 1,246 of these patents were licensed to US firms. On December 12, 1918, US authorities auctioned off 551 US patents by the German Bayer AG to the US Sterling Company (Alien Property Custodian 1919, p. 440-53). Sterling sold Bayer's dye business to Grasselli Chemical and used Bayer's dye patents to produce pharmaceuticals through its division, Winthrop Chemical. Critics of the auction argued that the Custodian had destroyed the German dye cartel merely "to build an American dye trust," and demanded the creation of an independent organization to distribute patents more broadly; this criticism led to the creation of the Chemical Foundation. Beginning in 1919, the US Chemical Foundation licensed another 695 Germanowned US patents to US firms (Alien Property Custodian 1919, p. 439 and Appendix 6 schedule 2; Hounshell and Smith 1988, p. 92.)

Licenses were non-exclusive; the average German-owned US patent was licensed to 2.5 firms, but the median patent was licensed to a single firm. Haynes (1945) reports licensees for 587 of 695 patents licensed by the Chemical Foundation. Although most German-owned patents were licensed to one or two US firms, in some cases a large number of US firms requested the same patent. For example, two patents by Krupp’s metallurgist Benno Strauss (1873-1844) for stainless steel (1,316,817, “Articles which require high resistance against corrosion” and 1,339,378 “Objects having great strength and great resistance against the action of acids”) were each licensed to 91 US firms. Both patents are in the USPTO subclass class 420/34 and German patent class 40b “alloys." Patent data (below) indicate that German patents for alloys nearly tripled after 1918 (from 4.95 patents per year to 16.92).

\section{B. Matching Technologies Across the US and German Patent System}

To identify research fields in which German inventors were affected by compulsory licensing, we created a new concordance between research fields in the US and German system. First, we used an existing USPTO concordance to match all 7,699 USPTO fields with 7,010 fields in the International Patent Classification (IPC). ${ }^{1}$ We then match IPC fields with all 513 fields in German patent system, using a corresponding classification by the German Patent Office (Appendix Table A1 and Figure A1). The USPTO, however, cautions that its USPTOIPC concordance "should be treated merely as suggestive of classification places in the two

\footnotetext{
${ }^{1}$ USPTO Office of Classification Support, Reference Tools Project. Available at http://www.uspto.gov/web/patents/classification/international/ipc/ipc8/ipc_concordance/ipcsel.htm.
} 
systems that may be similar," and warns that not all US and German fields can be matched with an IPC subclass.

To improve on the USPTO-IPC-GPO concordance, we exploit a reporting requirement as a result of the 1883 Paris Convention to identify US and German patents that were granted for the same invention. The Paris Convention's Right of Priority allows inventors to apply for patents in other member countries within 12 months of the original application. ${ }^{2}$ Germany ratified the Paris Convention in 1903, allowing inventors to apply for patents in Germany within 12 months of an application for the same invention in the United States. We exploit this rule to augment the USPTO-IPC-GPO concordance with information on fields that cover the same invention in the US and German system. Specifically, we search for references to US patent applications among the 71,770 German patents with application years after 1903 . $^{3}$ This search yields 1,343 pairs of German and US patents for the same invention, which we use to identify fields that cover the same invention in the US and in the German patent systems. With this additional information, we are able to match 3,533 licensed US patents with 167 fields in the GPO’s classification system (Appendix Table A1). ${ }^{4}$

TABle A1 - Concordance Between the USPTO And German Patent System

\begin{tabular}{lll}
\hline \hline & $\begin{array}{l}\text { Licensed patents } \\
(\mathrm{N}=1,246)\end{array}$ & $\begin{array}{l}\text { Confiscated patents } \\
(\mathrm{N}=4,706)\end{array}$ \\
\hline $\begin{array}{l}\text { US patents matched with at least one GPO subclass } \\
\text { 1) USPTO-IPC-GPO concordance }\end{array}$ & 968 & 3,533 \\
$\quad$ All patents matched & 954 & 3,464 \\
$\quad$ USPTO-IPC-GPO concordance only & 869 & 3,103 \\
2) USPTO \& GPO patents for the same invention & & 430 \\
$\quad$ All patents matched & 99 & 69 \\
USPTO \& GPO for the same invention only & 14 & \\
\hline \hline
\end{tabular}

Notes: Licensed patents are 1,246 German-owned patents, which the US Alien Property Custodian made available for licensing; confiscated patents are 4,706 German-owned US patents, which were available for licensing (from Haynes 1945, p. 498 and Alien Property Custodian 1919, p. 437). The USPTO-IPC concordance matches 7,699 USPTO fields with 7,010 fields in the International Patent Classification (IPC).

\footnotetext{
${ }^{2}$ International Convention for the Protection of Industrial Property 1883, Articles 4A and 4B. TRIPS requires all WTO members to comply with Article 4 of the Paris Convention.

${ }^{3}$ We first performed an automated search to match German with US patents (http://patft.uspto.gov/, accessed October 2012), using the title of the invention, the name of the inventor, and the application date. We hand-checked a random 10 percent sample of 46 patents; in this sample, 45 patents can be uniquely matched. 23 of 1,343 German patents with US application dates are for chemicals; 505 are by US nationals, 69 are by Germans, and 49 by nationals from 8 other countries.

${ }^{4}$ Using both primary and secondary (cross-references) fields of licensed German-owned US patents. Each US patent is assigned to one single primary field and may be assigned to one or more additional cross-reference fields, which patent examiners use to identify related technology fields. See Lampe and Moser (2014) for a detailed discussion.
} 
Another concordance, made available by the GPO (Figure A1), matches IPC fields with 513 GPO fields.

\begin{tabular}{|c|c|c|c|}
\hline \multicolumn{4}{|c|}{ PATENT ClASSIFICATION } \\
\hline & OPK & \multicolumn{2}{|c|}{ IPC } \\
\hline $\begin{array}{l}1 A \\
1 A \\
1 A \\
1 A \\
1 A \\
1 A \\
1 A \\
1 A \\
1 A \\
1 A \\
1 A\end{array}$ & $\begin{array}{l}3 \\
3-00 \\
4 \\
6-00 \\
7 \\
9 \\
10 \\
12-01 \\
12-10 \\
13\end{array}$ & $\begin{array}{l}B 038 \\
803 B \\
B 03 B \\
B 03 B \\
B 03 B \\
B 03 B \\
B 03 B \\
803 B \\
803 B \\
B 03 B \\
B 03 B \\
803 B \\
B 04 B\end{array}$ & $\begin{array}{r}3-16 \\
3-16 \\
3-28 \\
11-00 \\
3-32 \\
3-34 \\
3-12 \\
3-08 \\
3-30 \\
3-30 \\
3-00 \\
3-02 \\
3-50\end{array}$ \\
\hline
\end{tabular}

Notes: Excerpt from the concordance scheme between the International Patent Classification (IPC) and the classification system of the German Patent Office (DPK).

Combining these two concordances creates the USPTO-IPC-GPO concordance. To improve this classification we match fields across the USPTO and GPO system, using information on 1,343 USPTO and GPO patents for the same invention; this matching exploits a requirement to record the application date of USPTO patents after Germany ratified the Paris Convention in 1903. We use this requirement to identify USPTO and GPO patents that cover the same invention.

\section{Matching Patents with Firms}

To construct the firm-level data, we search the inventor field for all 79,591 German patents for 358 German words to denote firms, such as Firma, Gesellschaft, Gesellschaft mit beschraenkter Haftung or Aktiengesellschaft, as well abbreviations (GmbH and Akt.Ges) and alternative spellings (G.m.b.H. or Actiengesellschaft). For 30,499 patents that list a firm as an inventor, we combine alternative spellings of the firm's name to create 4,814 unique inventorlevel identifiers. For example, we connect different abbreviations for Aktien Gesellschaft für Anilin Fabrikation and Akt. Ges. für Anilin Fabrikation, to create the unique inventor-level identifier agfa. In another example, we combine alternative spellings of Griesheim Elektron and Griesheim Electron into griesheim-elektron. A total of 28,192 GPO patents cannot be linked to a firm; most of these patents belong to individuals, such as Dr. N. Sulzberger, Berlin who patented a new "process for preparing azo-dyestuff” (Patent No. 193,451). 
TABLE A2 - LiCENSED AND CONFISCATED PATENTS PER GPO SUBCLASS

\begin{tabular}{lcccc}
\hline \hline & All Fields & \multicolumn{2}{c}{$\begin{array}{c}\text { Fields with at least } \\
1 \text { licensed patents }\end{array}$} \\
& & & & \\
& $\mathrm{N}$ & Mean & $\mathrm{N}$ & Mean \\
\hline Licensed patents & 212 & 8.59 & 101 & $\begin{array}{c}18.04 \\
(38.02)\end{array}$ \\
& & & & $(53.65)$ \\
Confiscated patents & 212 & 19.51 & 101 & 37.56 \\
& & $(47.66)$ & & $(64.33)$ \\
\hline \hline
\end{tabular}

Notes: Licensed patents counts German-owned US patents that were licensed under the TWEA in each GPO subclass. Confiscated patents measures the number of patents that were seized by US authorities after the Trading With the Enemy Act in each GPO subclass. Standard deviations in parentheses.

TABLE A3 - GERMAN JOINT STOCK COMPANIES

\begin{tabular}{|c|c|c|c|c|c|}
\hline & \multicolumn{2}{|c|}{$\begin{array}{l}\text { German firms } \\
\text { with licensed } \\
\text { US patents }\end{array}$} & \multicolumn{2}{|c|}{$\begin{array}{c}\text { Other } \\
\text { German firms }\end{array}$} & \multirow[t]{2}{*}{ P-value } \\
\hline & $\mathrm{N}$ & Mean & $\mathrm{N}$ & Mean & \\
\hline Nominal capital stock (in year 2012 US\$) & 30 & $\begin{array}{l}108,343 \\
(38,284)\end{array}$ & 145 & $\begin{array}{l}40,755 \\
(8,253)\end{array}$ & 0.097 \\
\hline Employees & 13 & $\begin{array}{c}6,197 \\
(4,867.71)\end{array}$ & 50 & $\begin{array}{c}2,466 \\
(963.42)\end{array}$ & 0.475 \\
\hline Year of incorporation & 30 & $\begin{array}{c}1893 \\
(2.61)\end{array}$ & 145 & $\begin{array}{c}1892 \\
(1.37)\end{array}$ & 0.613 \\
\hline
\end{tabular}

Notes: Joint stock companies (Aktiengesellschaften, or AGs) are corporations that are owned by shareholders, who can trade their shares on the stock market. 175 of 4,814 firms are listed in the registries of German AGs, (Handbuch der Deutschen Aktiengesellschaften, 1911 and 1912). Year of incorporation refers to the year in which the firm was incorporated as a joint stock company. Standard errors clustered at the firm level in parentheses. 


\section{Figure A2 - AnNual Renewal FeEs PER YeAR AFter Patent Grant}

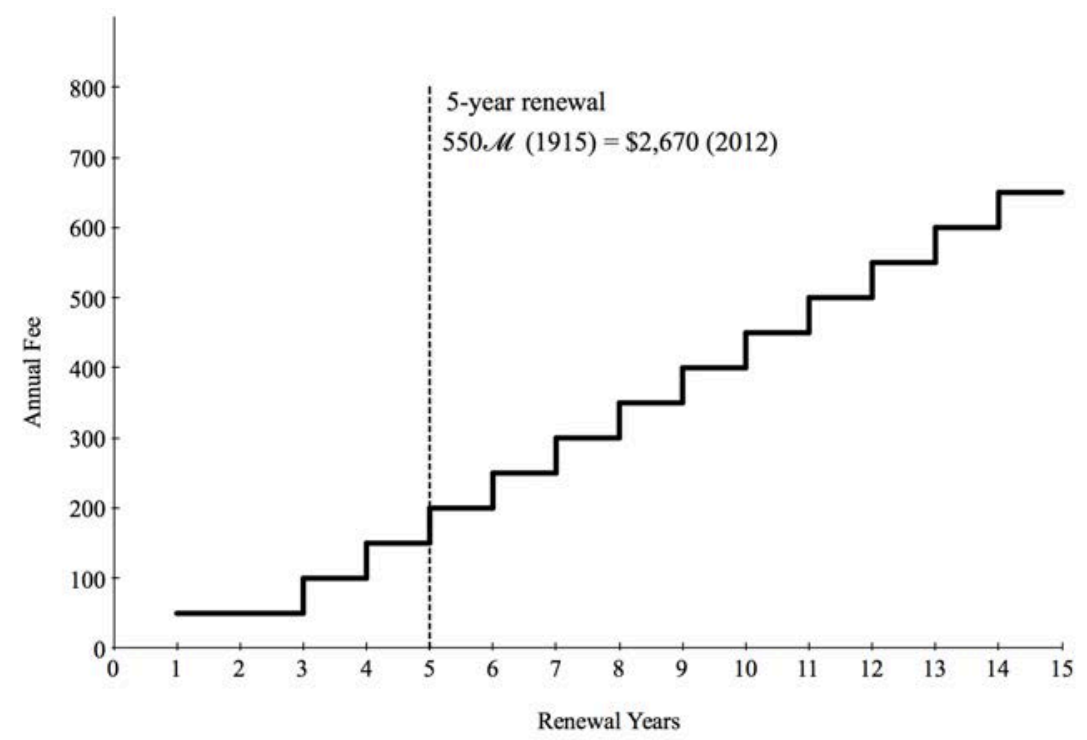

Notes: In the first two years, renewal fees were $50 \mathcal{M}$ per year, roughly \$243 2012 dollars using purchasing power conversions, and \$1,340 using income value (Williamson 2014). Beginning in the third year, renewal fees per year increased by $50 \mathcal{M}$ each year, reaching a total of $700 \mathcal{M}$ in the final 15th year of patent life. Patents that were renewed for 5 years or more required

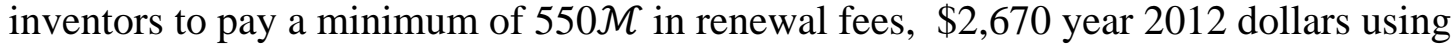
purchasing power conversions, and $\$ 14,700$ using income conversions.

Figure A3 - RENEWAL DATA FOR GERMAN PATENTS 1900-1930

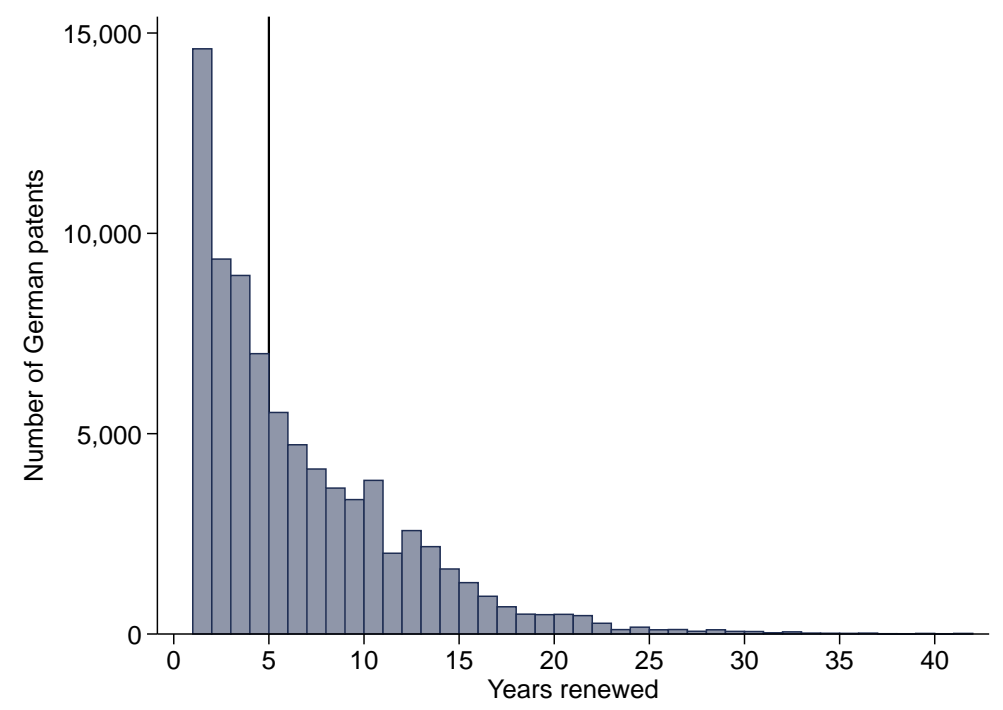

Notes: Years renewed are measured at the last year in which a patentee pays the renewal fee that the GPO required to keep a patent active. Fifty percent of all patents were renewed for 5 years or more; the average patent was renewed for 6 years. Data include the complete renewal history of 79,591 German patents for chemical inventions with application years between 1900 and 1930. We have collected these data from German-language copies of the Annual Reports of the GPO between 1901 and 1942. 
Figure A4 - German-OWned Patents Per Field ANd Application Year

PANEL A - FIELDS WITH AND WITHOUT LICENSED PATENTS

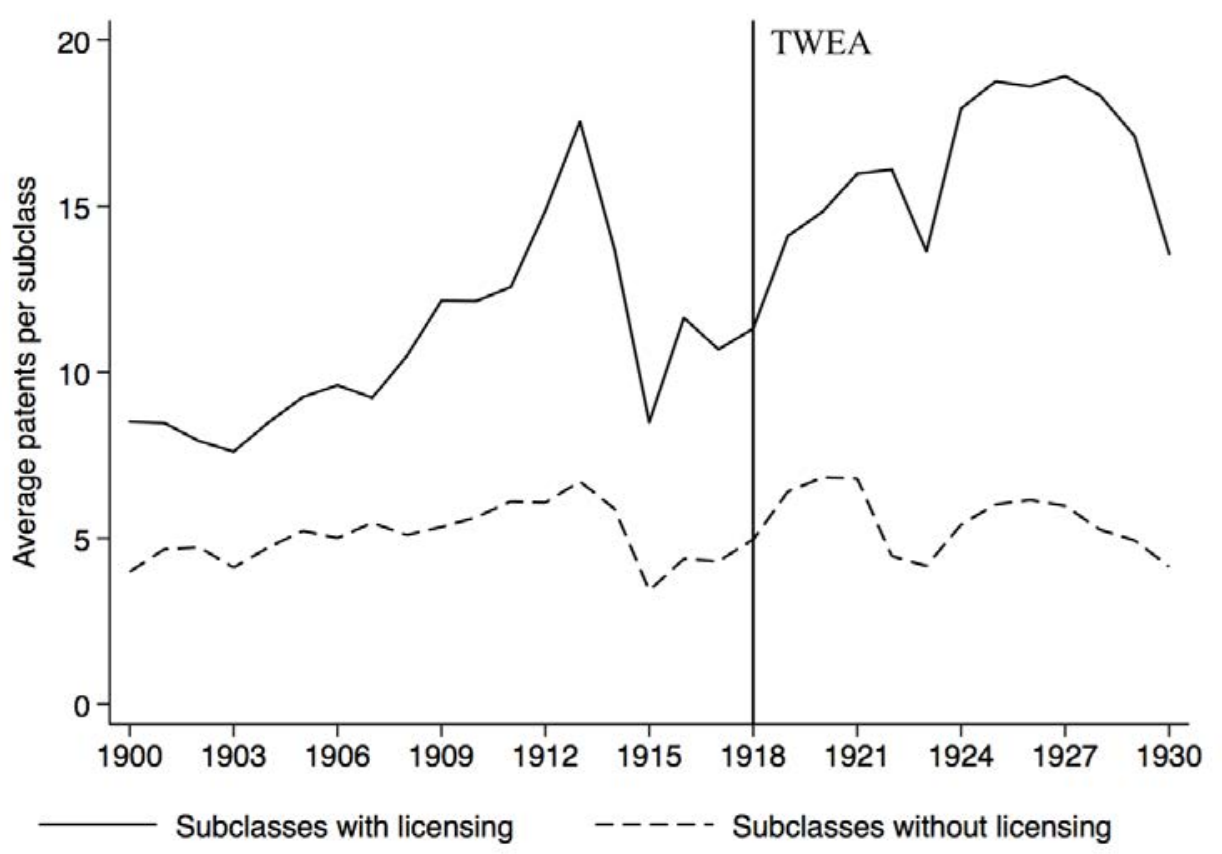

Panel B - Quartiles of The Distribution of LiCEnsed Patents

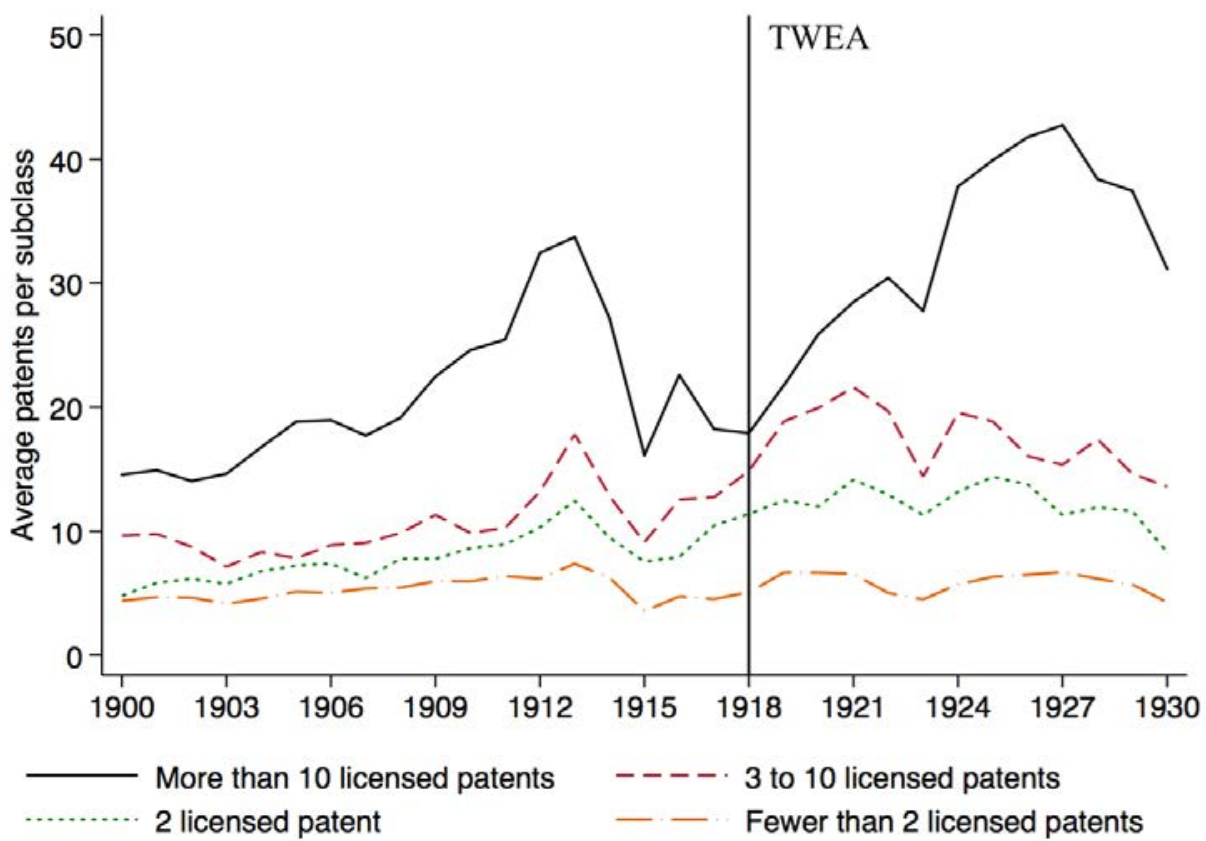

Notes: Data include 58,691 GPO patents by German inventors with application years between January 1, 1900 and December 31, 1930. We have collected these data from the GPO's Annual Report (Verzeichnis der im Vorjahre erteilten Patente) between 1900 and 1932. 101 fields with licensing each include at least one US patent by a German firm was licensed under the TWEA; 111 fields without licensing include no licensed patents. 
Figure A5 - ANNUAL TREATMENT EFFECTS

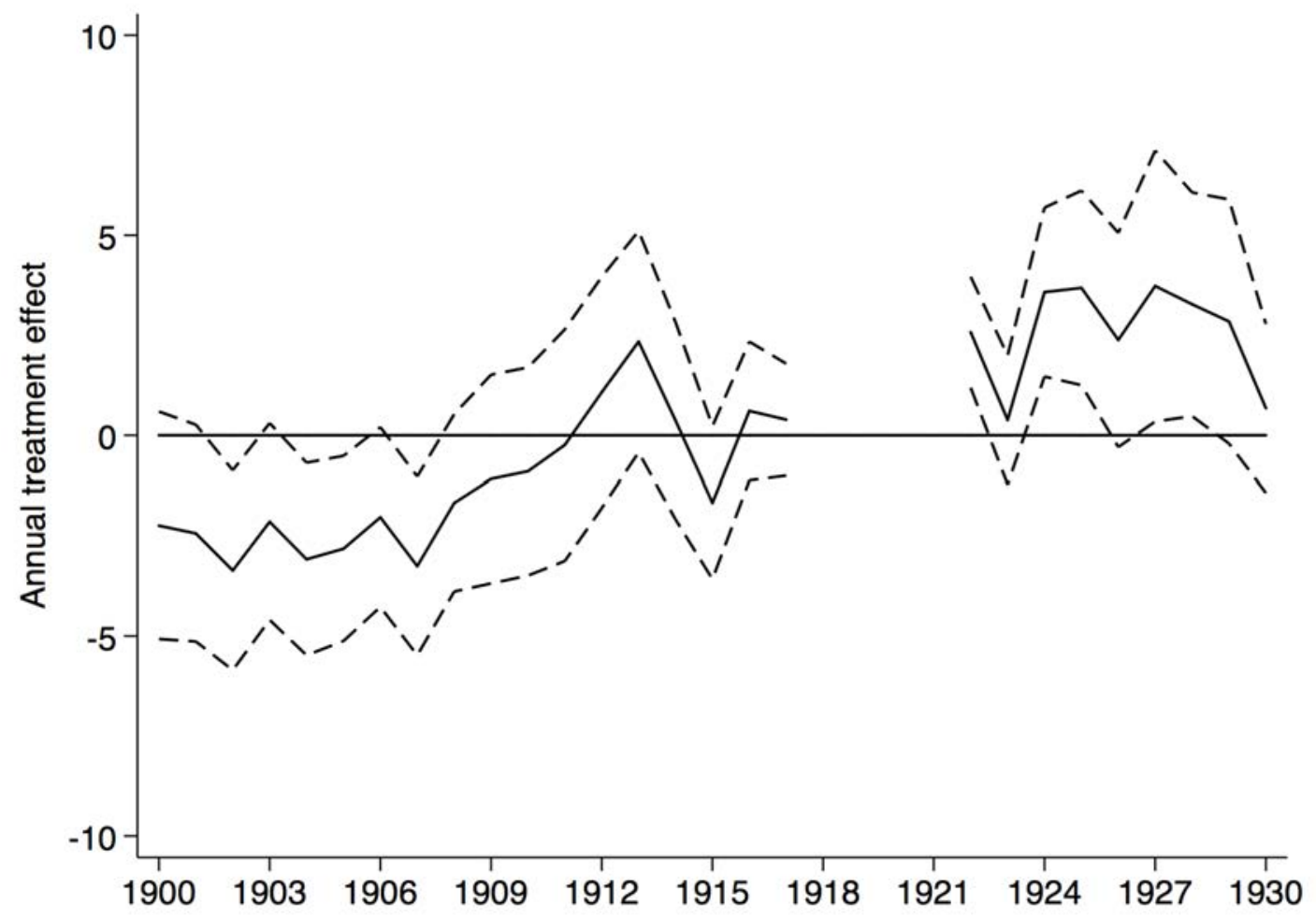

Notes: Data include all 71,963 applications for patents on chemical inventions between 1900 and 1930, excluding the war years 1915 to 1918. The annual treatment effects $\beta_{1 t}$ are estimated from the regression patents $s_{c t}=\beta_{0}+\Sigma_{\mathrm{t}} \beta_{1 t} \bullet$ field with licensed patents $s_{c} \bullet \delta_{t}+\beta_{2} \bullet$ patents by US inventors $_{c t}+\beta_{3} \bullet$ patents by other foreign inventors $s_{c t}+\Sigma_{\mathrm{c}} \phi_{c} \bullet$ field $_{c} \bullet$ preTWEA $_{t} \bullet t+\delta_{t}+\theta_{c}$ $+\varepsilon_{c t}$. The omitted years are 1918-1921. 90 percent confidence intervals. 
Figure A6 - PATENTS THAT WERE RENEWED FOR FIVE YEARS OR MORE

PANEL A - FIELDS WITH AND WITHOUT LICENSED PATENTS

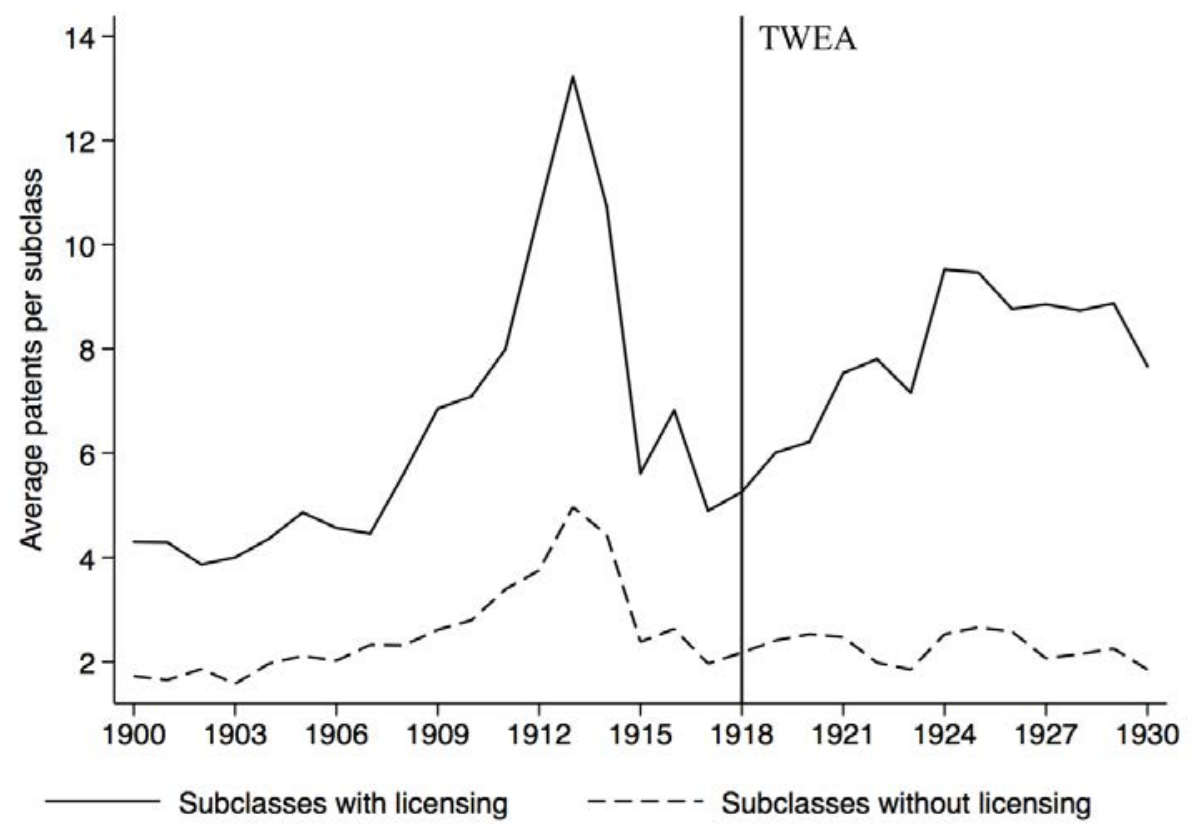

PANel B - QuARTiles of The Distribution of LiCEnsed PATENTS

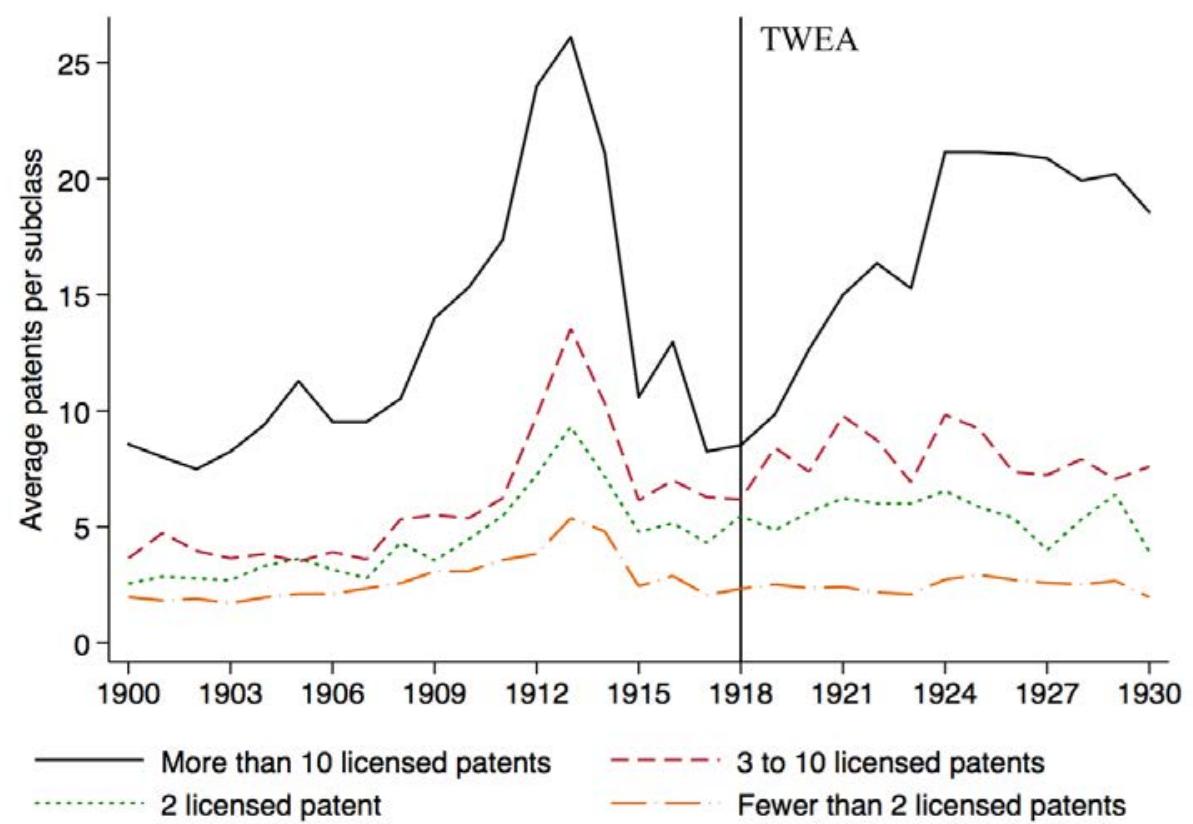

Notes: Data include 30,017 GPO patents by German inventors that were renewed for 5 years with application between January 1, 1900 and December 31, 1930. We have constructed these data by reconstructing the renewal history of all GPO patents by German inventors from the GPO's Annual Report (Verzeichnis der im Vorjahre erteilten Patente) between 1900 and 1942. 101 fields with licensing each include at least one US patent by a German firm was licensed under the TWEA; 111 other fields without licensing include no licensed patents. 
Figure A7 - Patents by Entrants with and without Previous Patents

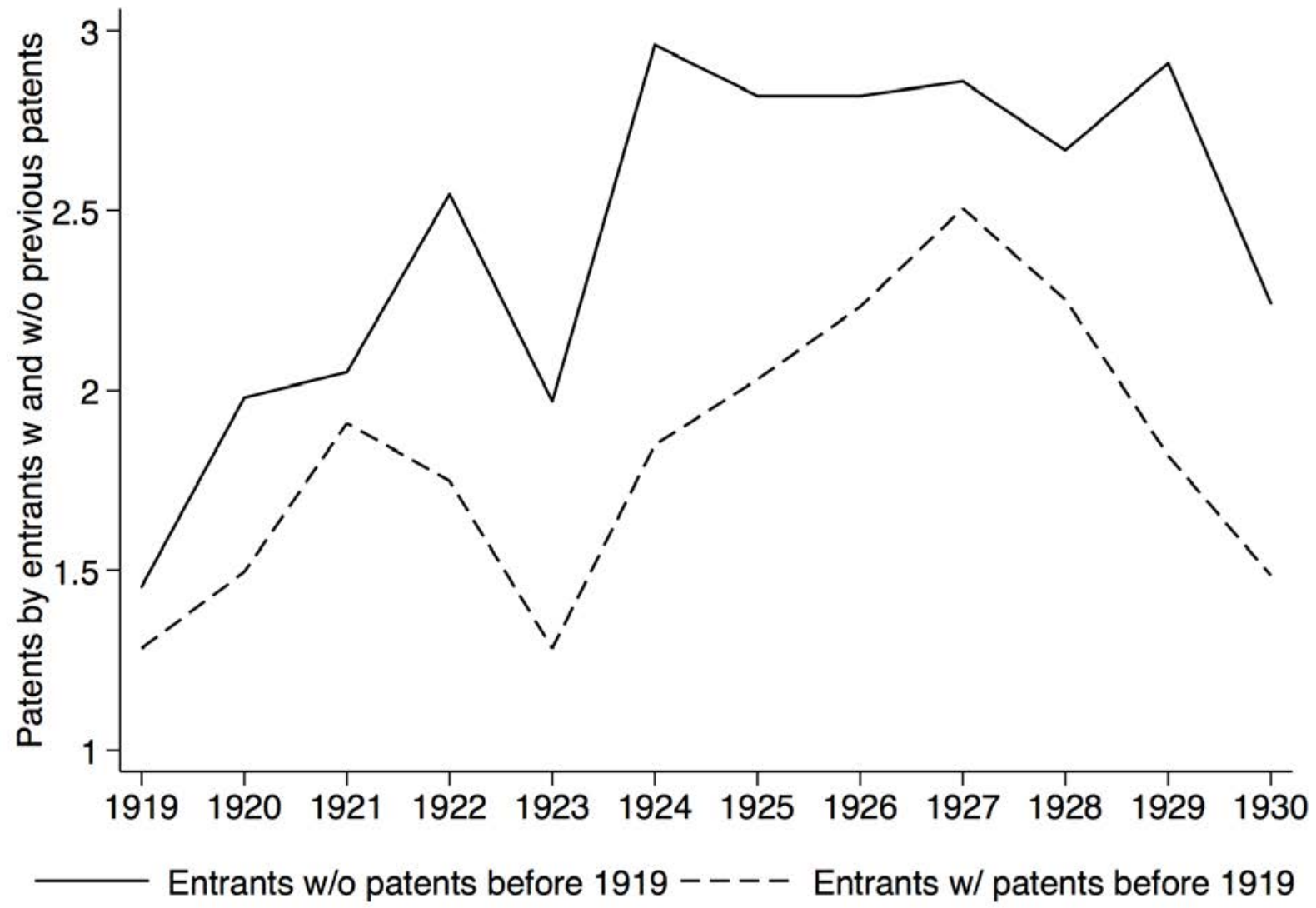

Notes: Entrants without previous patents before 1919 are patents by new entrants in fields with licensing without patents before 1919. This includes patents by firms that never patented before and by firms that have patented only after 1919 in other technology fields. Entrants with previous patents before 1919 are patents by new entrants in fields with licensing that patented in other chemical fields before 1919. 
FiguRE A8 - EstimAted EFFECT OF COMPULSORY LiCENSING ON COMPETITION

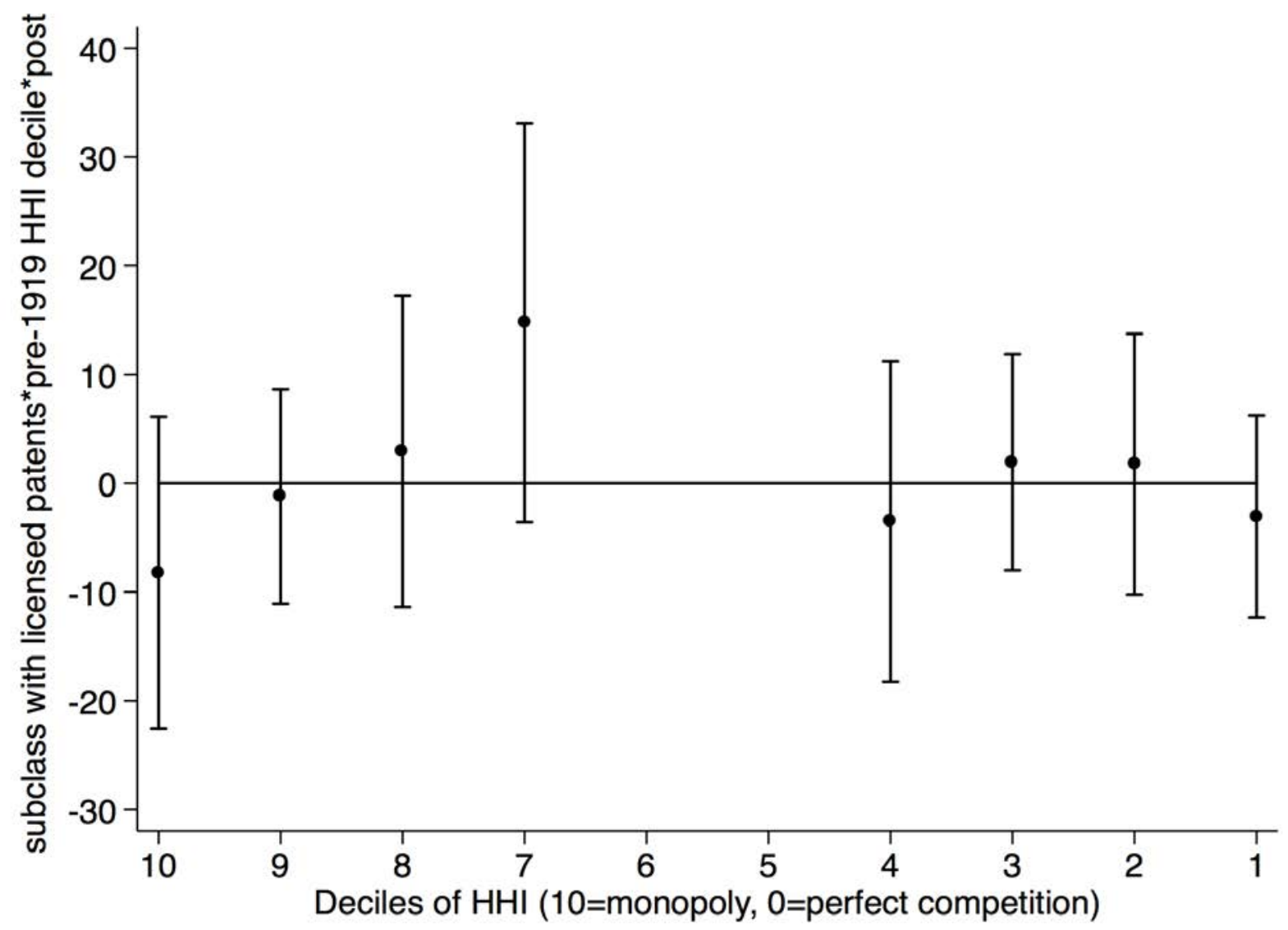

Notes: The figure plots estimates of the interaction subclass with licensed patents ${ }_{c}$ pre-1919

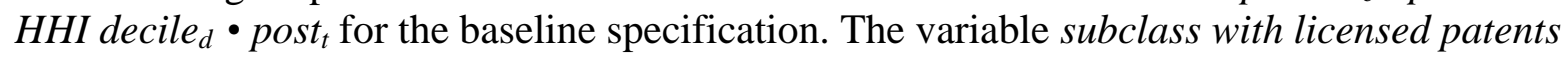
equals one for 101 fields of German patents, in which at least one German-owned US patent became subject to compulsory licensing in 1918. The indicator variable post equals 1 for all years after 1918; pre-1919 $\mathrm{HHI}$ decile $_{d}$ is a set of indicators for the deciles of the pre-1919 distribution of the HHI, which measures pre-TWEA competition in patenting. The $5^{\text {th }}$ and $6^{\text {th }}$ decile are omitted; bars present the $95^{\text {th }}$ percent confidence intervals reported. Data include all 79,591 applications for patents on chemical inventions between 1900 and 1930. 
Table A4 - OLS, Dependent Variable is Patents Per SubClass ANd Year EXCLuding War Years 1915-1918

\begin{tabular}{|c|c|c|c|c|c|c|}
\hline & $(1)$ & $(2)$ & $(3)$ & $(4)$ & $(5)$ & $(6)$ \\
\hline Subclass with licensed patents * post & $\begin{array}{l}3.221 * * * \\
(0.982)\end{array}$ & $\begin{array}{l}5.362 * * * \\
(1.533)\end{array}$ & $\begin{array}{l}5.668 * * * \\
(1.436)\end{array}$ & $\begin{array}{l}5.494 * * * \\
(1.421)\end{array}$ & & \\
\hline Licensed patents * post & & & & & $\begin{array}{l}0.192 * * * \\
(0.070)\end{array}$ & $\begin{array}{l}0.455^{* * *} \\
(0.122)\end{array}$ \\
\hline Licensed patents ${ }^{2} *$ post & & & & & $\begin{array}{l}-0.001 * * * \\
(0.000)\end{array}$ & $\begin{array}{l}-0.001^{* * *} \\
(0.000)\end{array}$ \\
\hline Patents by US inventors & $\begin{array}{l}0.969 * * * \\
(0.151)\end{array}$ & & $\begin{array}{l}0.762 * * * \\
(0.165)\end{array}$ & $\begin{array}{l}0.966 * * * \\
(0.151)\end{array}$ & $\begin{array}{l}0.924 * * * \\
(0.154)\end{array}$ & $\begin{array}{l}0.717 * * * \\
(0.158)\end{array}$ \\
\hline Patents by other foreign inventors & $\begin{array}{l}1.461^{* * *} \\
(0.227)\end{array}$ & & $\begin{array}{l}1.421^{* * *} \\
(0.265)\end{array}$ & $\begin{array}{l}1.453^{* * *} \\
(0.226)\end{array}$ & $\begin{array}{l}1.359 * * * \\
(0.158)\end{array}$ & $\begin{array}{l}1.236^{* * *} \\
(0.162)\end{array}$ \\
\hline \multicolumn{7}{|c|}{ Standard errors (in parentheses) are clustered at the level of fields, $* * * \mathrm{p}<0.01, * * \mathrm{p}<0.05, * \mathrm{p}<0.1$} \\
\hline Mean in fields with licensing 1900-18 & 10.77 & 10.77 & 10.77 & 10.77 & 10.77 & 10.77 \\
\hline Subclass-specific pre-trends & No & No & Yes & No & No & Yes \\
\hline Pre-trend for fields with licensing & No & No & No & Yes & No & No \\
\hline Subclass fixed effects & Yes & Yes & Yes & Yes & Yes & Yes \\
\hline Year fixed effects & Yes & Yes & Yes & Yes & Yes & Yes \\
\hline $\mathrm{N}$ & 5,724 & 5,724 & 5,724 & 5,724 & 5,724 & 5,724 \\
\hline
\end{tabular}

Notes: Data include all 71,963 applications for patents on chemical inventions between 1900 and 1930, excluding the war years 1915 to 1918. Subclass with licensed patents is an indicator variable that equals 1 for 101 German fields, in which at least one US patent became subject to compulsory licensing. The indicator variable post equals 1 for all years after 1918. The variable licensed patents measures the number of patents that became subject to licensing. Patents by US inventors controls for the number of patents that the GPO issued to residents of the United States in subclass $c$ and year $t$; patents by other foreign inventors controls for the number of patents that the GPO issued to residents of other foreign countries. 
TABLE A5 - TOP TEN FIELDS By NUMBER OF LiCENSED PATENTS

\begin{tabular}{|c|c|c|c|c|c|}
\hline \multirow[t]{2}{*}{ Class number } & \multirow[t]{2}{*}{ Class name } & \multirow[t]{2}{*}{ Confiscated patents } & \multirow[t]{2}{*}{ Licensed patents } & \multicolumn{2}{|c|}{ German patents per year } \\
\hline & & & & $1900-1918$ & 1919-1930 \\
\hline $22 \mathrm{a}$ & Azo-dyes & 863 & 436 & 28.79 & 24.17 \\
\hline 120 & Hydrocarbons & 621 & 242 & 88.84 & 173.42 \\
\hline $12 \mathrm{i}$ & Metalloids & 349 & 146 & 52.05 & 103.25 \\
\hline $12 \mathrm{q}$ & Aminophenols & 289 & 110 & 49.68 & 82.50 \\
\hline $12 \mathrm{k}$ & Ammonia & 177 & 108 & 18.95 & 23.50 \\
\hline $8 \mathrm{~m}$ & Dyeing & 258 & 105 & 23.47 & 27.50 \\
\hline $85 b$ & Water purification & 73 & 54 & 7.89 & 8.42 \\
\hline $8 n$ & Calico printing & 151 & 52 & 9.11 & 8.50 \\
\hline $8 \mathrm{k}$ & Mercerizing & 159 & 49 & 9.47 & 12.17 \\
\hline $22 \mathrm{~g}$ & Inks & 126 & 36 & 12.42 & 28.83 \\
\hline
\end{tabular}

Notes: Confiscated patents are patents that were seized by US authorities under the TWEA and made available for licensing. Licensed patents are German-owned US patents that US firms licensed under the TWEA. German patents per year counts the number of German patents by German inventors, measured in their application year. 
TABLE A6 - ITT, DEPENDENT VARIABLE IS PATENTS RENEWED FOR AT LEAST 5 YEARS PER SUBCLASS AND YEAR

\begin{tabular}{|c|c|c|c|c|c|c|}
\hline & $(1)$ & $(2)$ & $(3)$ & $(4)$ & (5) & $(6)$ \\
\hline Subclass with confiscated patents * post & $\begin{array}{l}0.833 * * \\
(0.400)\end{array}$ & $\begin{array}{l}1.493 * * * \\
(0.514)\end{array}$ & $\begin{array}{l}2.270^{* * *} \\
(0.659)\end{array}$ & $\begin{array}{l}2.205^{* * *} \\
(0.654)\end{array}$ & & \\
\hline Confiscated patents * post & & & & & $\begin{array}{l}0.033^{* * *} \\
(0.011)\end{array}$ & $\begin{array}{l}0.074 * * * \\
(0.020)\end{array}$ \\
\hline Confiscated patents ${ }^{2} *$ post & & & & & $\begin{array}{l}-0.000 * * \\
(0.000)\end{array}$ & $\begin{array}{l}-0.000^{* * *} \\
(0.000)\end{array}$ \\
\hline Patents by US inventors & $\begin{array}{l}0.835^{* * *} \\
(0.150)\end{array}$ & & $\begin{array}{l}0.712 * * * \\
(0.164)\end{array}$ & $\begin{array}{l}0.830 * * * \\
(0.150)\end{array}$ & $\begin{array}{l}0.759 * * * \\
(0.135)\end{array}$ & $\begin{array}{l}0.626 * * * \\
(0.139)\end{array}$ \\
\hline Patents by other foreign inventors & $\begin{array}{l}1.204^{* * *} \\
(0.187)\end{array}$ & & $\begin{array}{l}1.147 * * * \\
(0.208)\end{array}$ & $\begin{array}{l}1.200^{* * *} \\
(0.187)\end{array}$ & $\begin{array}{l}1.120^{* * *} \\
(0.151)\end{array}$ & $\begin{array}{l}1.059 * * * \\
(0.162)\end{array}$ \\
\hline \multicolumn{7}{|c|}{ Standard errors (in parentheses) are clustered at the level of fields, ${ }^{* * *} \mathrm{p}<0.01,{ }^{* *} \mathrm{p}<0.05, * \mathrm{p}<0.1$} \\
\hline Mean in fields with licensing 1900-18 & 6.28 & 6.28 & 6.28 & 6.28 & 6.28 & 6.28 \\
\hline Subclass-specific pre-trends & No & No & Yes & No & No & Yes \\
\hline Pre-trend for fields with confiscated patents & No & No & No & Yes & No & No \\
\hline Subclass fixed effects & Yes & Yes & Yes & Yes & Yes & Yes \\
\hline Year fixed effects & Yes & Yes & Yes & Yes & Yes & Yes \\
\hline $\mathrm{N}$ & 6,572 & 6,572 & 6,572 & 6,572 & 6,572 & 6,572 \\
\hline
\end{tabular}

Notes: Data include all 39,682 applications for patents on chemical inventions between 1900 and 1930 that were renewed for a minimum of 5 years. Data on renewal decisions come from archival records of renewed patents from the Annual Reports of the German patent office between 1901 and 1942. Subclass with confiscated patents is an indicator variable that equals 1 for 171 German fields in which at least one US patent was confiscated after the TWEA. The indicator variable post equals 1 for all years after 1918. Confiscated patents measures the number of patents that were seized by US authorities after the Trading With the Enemy Act in subclass $c$. Patents by US inventors controls for the number of patents that the German Patent Office issued to residents of the United States in subclass $c$ and year $t$; patents by other foreign inventors controls for the number of patents that the German Patent Office issued to residents of other foreign countries. 
TABle A7 - Firms that Merged to Create IG FARBEN: ExPOSURE TO LiCENSING AND Changes IN PATENTING

\begin{tabular}{|c|c|c|c|c|c|c|c|c|c|c|}
\hline & \multirow{2}{*}{\multicolumn{2}{|c|}{ Licensed patents }} & \multicolumn{8}{|c|}{ Patents per subclass and year } \\
\hline & & & & All pa & tents & & Pate & ts rener & $\mathrm{ed} \geq 5 \mathrm{y}$ & ars \\
\hline & \multirow[b]{2}{*}{$\begin{array}{c}\text { All } \\
\text { fields }\end{array}$} & \multirow[b]{2}{*}{$\begin{array}{c}\text { Azo-dyes } \\
(22 a)\end{array}$} & \multicolumn{2}{|c|}{$\begin{array}{l}\text { Fields with } \\
\text { licensed patents }\end{array}$} & \multicolumn{2}{|c|}{$\begin{array}{l}\text { Other } \\
\text { Fields }\end{array}$} & \multicolumn{2}{|c|}{$\begin{array}{l}\text { Fields with } \\
\text { licensed patents }\end{array}$} & \multicolumn{2}{|c|}{$\begin{array}{l}\text { Other } \\
\text { fields }\end{array}$} \\
\hline & & & $\begin{array}{l}1900- \\
1924 \\
\end{array}$ & $\begin{array}{l}1925- \\
1930 \\
\end{array}$ & $\begin{array}{l}1900- \\
1924 \\
\end{array}$ & $\begin{array}{c}1925- \\
1930 \\
\end{array}$ & $\begin{array}{c}1900- \\
1924 \\
\end{array}$ & $\begin{array}{c}1925- \\
1930 \\
\end{array}$ & $\begin{array}{l}1900- \\
1924 \\
\end{array}$ & $\begin{array}{l}1925- \\
1930 \\
\end{array}$ \\
\hline Bayer & 551 & 258 & $\begin{array}{c}1.19 \\
(3.66)\end{array}$ & $\begin{array}{c}4.16 \\
(10.02)\end{array}$ & $\begin{array}{c}0.22 \\
(0.83)\end{array}$ & $\begin{array}{c}0.46 \\
(0.98)\end{array}$ & $\begin{array}{c}0.97 \\
(3.08)\end{array}$ & $\begin{array}{c}2.51 \\
(5.73)\end{array}$ & $\begin{array}{c}0.23 \\
(0.78)\end{array}$ & $\begin{array}{c}0.34 \\
(0.70)\end{array}$ \\
\hline$B A S F$ & 308 & 82 & $\begin{array}{c}0.99 \\
(2.70)\end{array}$ & $\begin{array}{c}3.08 \\
(5.93)\end{array}$ & $\begin{array}{c}0.26 \\
(0.94)\end{array}$ & $\begin{array}{c}0.45 \\
(1.12)\end{array}$ & $\begin{array}{c}0.78 \\
(2.21)\end{array}$ & $\begin{array}{c}1.94 \\
(3.71)\end{array}$ & $\begin{array}{c}0.25 \\
(0.85)\end{array}$ & $\begin{array}{c}0.30 \\
(0.65)\end{array}$ \\
\hline Hoechst & 104 & 34 & $\begin{array}{c}1.12 \\
(3.32)\end{array}$ & $\begin{array}{c}3.01 \\
(6.67)\end{array}$ & $\begin{array}{c}0.44 \\
(1.78)\end{array}$ & $\begin{array}{c}0.78 \\
(2.24)\end{array}$ & $\begin{array}{c}0.77 \\
(2.36)\end{array}$ & $\begin{array}{c}1.57 \\
(3.55)\end{array}$ & $\begin{array}{c}0.44 \\
(1.56)\end{array}$ & $\begin{array}{c}0.53 \\
(1.36)\end{array}$ \\
\hline Griesheim-Elektron & 57 & 12 & $\begin{array}{c}0.33 \\
(1.10)\end{array}$ & $\begin{array}{c}1.39 \\
(2.82)\end{array}$ & $\begin{array}{c}0.09 \\
(0.40)\end{array}$ & $\begin{array}{c}0.35 \\
(1.04)\end{array}$ & $\begin{array}{c}0.27 \\
(0.90)\end{array}$ & $\begin{array}{c}0.95 \\
(1.74)\end{array}$ & $\begin{array}{c}0.09 \\
(0.43)\end{array}$ & $\begin{array}{c}0.21 \\
(0.73)\end{array}$ \\
\hline$A G F A$ & 38 & 26 & $\begin{array}{c}0.42 \\
(1.31)\end{array}$ & $\begin{array}{c}1.62 \\
(4.05)\end{array}$ & $\begin{array}{c}0.18 \\
(0.78)\end{array}$ & $\begin{array}{c}0.14 \\
(0.35)\end{array}$ & $\begin{array}{c}0.26 \\
(0.84)\end{array}$ & $\begin{array}{c}0.86 \\
(2.01)\end{array}$ & $\begin{array}{c}0.15 \\
(0.69)\end{array}$ & $\begin{array}{c}0.05 \\
(0.12)\end{array}$ \\
\hline Weiler Ter Meer & 1 & 1 & $\begin{array}{c}0.07 \\
(0.40)\end{array}$ & $\begin{array}{c}0.28 \\
(1.10)\end{array}$ & $\begin{array}{c}0.02 \\
(0.16)\end{array}$ & $\begin{array}{c}0.00 \\
(0.00)\end{array}$ & $\begin{array}{c}0.03 \\
(0.19)\end{array}$ & $\begin{array}{c}0.13 \\
(0.57)\end{array}$ & $\begin{array}{c}0.02 \\
(0.14)\end{array}$ & $\begin{array}{c}0.00 \\
(0.00)\end{array}$ \\
\hline
\end{tabular}

Notes: Data include all German patents on chemical inventions by the six firms that merged into IG Farben - AGFA, Bayer, BASF, Hoechst, Griesheim-Elektron, and Chemische Fabrik vorm. Weiler Ter Meer - with application years between 1900 and 1930. Licensed patents are German-owned patents, which the US Alien Property Custodian made available for licensing after the 1918 US TWEA. Fields with licensed patents denotes 101 out of 212 GPO chemical fields, in which at least 1 US patent became subject to compulsory licensing. Standard deviations in parentheses. 
TABLE A8 - EXCLUding DATA AFTER 1924, PATENTS RENEWED FOR AT LEAST 5 YEARS PER FiRM, SUBCLASS, AND YEAR

\begin{tabular}{|c|c|c|c|c|}
\hline & $(1)$ & $(2)$ & $(3)$ & $(4)$ \\
\hline Subclass w licensed patents * firm w licensed patents * post & $\begin{array}{l}0.130 * * \\
(0.052)\end{array}$ & $\begin{array}{l}0.125 * * \\
(0.052)\end{array}$ & $\begin{array}{l}0.164 \\
(0.000)\end{array}$ & $\begin{array}{l}0.130 * * \\
(0.052)\end{array}$ \\
\hline Subclass w licensed patents * post & $\begin{array}{l}0.014^{* *} \\
(0.006)\end{array}$ & $\begin{array}{l}0.028 * * * \\
(0.007)\end{array}$ & $\begin{array}{l}0.015 \\
(0.000)\end{array}$ & $\begin{array}{l}0.014^{* *} \\
(0.006)\end{array}$ \\
\hline Patents by US inventors & $\begin{array}{l}0.002 \\
(0.001)\end{array}$ & & $\begin{array}{l}0.001 \\
(0.000)\end{array}$ & $\begin{array}{l}0.002 * \\
(0.001)\end{array}$ \\
\hline Patents by other foreign & $\begin{array}{l}0.003 * * * \\
(0.001)\end{array}$ & & $\begin{array}{l}0.003 \\
(0.000)\end{array}$ & $\begin{array}{l}0.003^{* * *} \\
(0.001)\end{array}$ \\
\hline Patents by individuals & $\begin{array}{l}0.003^{* * *} \\
(0.000)\end{array}$ & & $\begin{array}{l}0.003 \\
(0.000)\end{array}$ & $\begin{array}{l}0.003^{* * *} \\
(0.000)\end{array}$ \\
\hline \multicolumn{5}{|c|}{ Standard errors (in parentheses) are clustered at the level of firms, $* * * p<0.01,{ }^{* *} \mathrm{p}<0.05,{ }^{*} \mathrm{p}<0.1$} \\
\hline Mean for firms with licensed patents, 1900-18 & 0.46 & 0.46 & 0.46 & 0.46 \\
\hline Subclass-specific pre-trends & No & No & Yes & No \\
\hline Pre-trend for firms with licensing & No & No & No & Yes \\
\hline Subclass fixed effects & Yes & Yes & Yes & Yes \\
\hline Firm fixed effects & Yes & Yes & Yes & Yes \\
\hline Year fixed effects & Yes & Yes & Yes & Yes \\
\hline $\mathrm{N}$ (Subclass-firm-year) & 132,425 & 132,425 & 132,425 & 132,425 \\
\hline
\end{tabular}

Notes: Regressions also include firms $w$ licensed patents * post, licensed patents $*$ firms $w$ licensed patents, and subclass $w$ licensed patents * firms w licensed patents. Data include GPO patents for chemicals with application years between 1900 and 1924 that were renewed for a minimum of 5 years. Data on renewal decisions come from the Annual Reports of the GPO between 1901 and 1942. Firm $w$ licensed patents equals 1 for 50 German firms that owned at least 1 US patents that became subject to compulsory licensing. The indicator variable post equals 1 for years after 1918. Subclass $w$ licensed patents is an indicator variable that equals 1 for 101 German fields, in which at least 1 US patents became subject to compulsory licensing. Patents by US inventors controls for GPO patents to US residents in subclass $c$ and year $t$; patents by other foreign and patents by individual inventors control for GPO patents to other foreign and individual (non-firm) inventors, respectively. 